\title{
Application of Arbuscular Mycorrhizae Glomus iranicum var. tenuihypharum var. nova in Intensive Agriculture: A Study Case
}

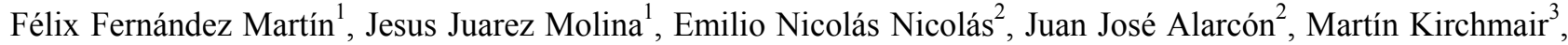 \\ Francisco José García ${ }^{1}$, Antonio José Bernabe Garcia ${ }^{1}$ and Camille Bernal ${ }^{1}$ \\ 1. SYMBORG S.L., Campus de Espinardo 7, Edificio CEEIM, CP, Murcia 30100, Spain \\ 2. CEBAS-CSIC, Campus de Espinardo, CP, Murcia 30100, Spain \\ 3. Universität Innsbruck, Institut für Mikrobiologie, Technikerstr 25, Innsbruck A-6020, Austria
}

\begin{abstract}
Intensive agriculture contributes to a decrease in microbial biomass and crop yields, while accelerating soil degradation. Arbuscular mycorrhizae associations have direct benefits for plant nutrition, and may be considered a useful tool in modern agriculture. Notwithstanding the widespread knowledge of these benefits, their use in intensive farming systems has until now been ineffectual, because most mycorrhizal species have low tolerance toward high concentrations of nutrients and are poorly adapted to the soil and/or mycorrhizal functioning. The aim of this work was to test the efficacy of an arbuscular mycorrhizal (AM) fungus, Glomus iranicum var. tenuihypharum on lettuce and table grape crops in different intensive farming systems. The variables studied were root colonization percentage, external mycelium concentration, gas exchange, photosynthetic activity, root starch concentration and plant nutrition. The main finding was that the fungus is tolerant of a wide range of soil $\mathrm{pH}$ values, high salinity levels and abundant external mycelium. In lettuce, it produced significant increases in plant physiological activity and productivity (10\%-15\%); and in table grapes, increases of $12 \%-45 \%$ in yield were achieved for more than three years in Crimson variety, and significant increases in fruit cluster weight, color uniformity and Brix $\left({ }^{\circ} \mathrm{Bx}\right)$. The AM species is protected by two patents and is a component of MycoUp, MycoUp Activ, Resid HC and Resid MG, whose commercial application has spread to more than 30 countries, with increments in crop yields of $8 \%-45 \%$ in lines as varied as leaf vegetables, berries, fruit, olives, grapes, greenhouse crops and cereals.
\end{abstract}

Key words: Arbuscular mycorrhizal, Glomus iranicum var. tenuihypharum, intensive agriculture, gas exchange, root starch concentration, photosynthetic activity.

\section{Introduction}

Intensive agriculture as a production system is characterized by high inputs of capital, fertilizers and pesticides, although such high inputs have allowed a substantial increase in production [1].

However, among its many disadvantages, intensive farming alters the environment in many ways, decreasing microbial populations and promoting soil erosion, while altering the biology of rivers and lakes as well.

In the last decade, new ways of practicing intensive

Corresponding author: Félix Fernández Martín, Ph.D., research field: mycorrhizal plant interactions. agriculture have emerged, including biointensive agriculture, which focuses on maximizing efficiency compared with conventional practices, and increasing yield per energy and area input. Unfortunately, the yields of many crops often diminish in the long term and the changes involved present new challenges to farmers, who rely on modern farming equipment that is best suited to monocultures $[2,3]$.

This phenomenon has resulted in a drastic reduction in the microbiota in soils, leading to a reduced microbial population, which is unbalanced and dependent on the above inputs, commonly resulting in fungal or bacterial diseases [4].

Moreover, in the case of highly profitable crops, 
such as berries, leafy vegetables or greenhouse crops, it is common to use soil disinfection programs to eliminate the microbial imbalance generated by this praxis. Consequently, there is a gradual process of enrichment with the microbial populations contained in the irrigation water and in the environment, all random and resulting in a low disease pressure of the soil's phytopathogens, such as phytonematodes or fungi, including Fusarium sp., Rhizoctonia sp., Sclerotinia sp., Botrytis sp., Pythium sp. and Oidio sp., etc. $[5,6]$.

On the other hand, the world is in transition from an era of food abundance to one of scarcity. With $40 \%$ of the planet's land devoted to human food production, up from $7 \%$ in 1700 , and as the world's demand for food increasing to reach a predicted $70 \%$ by 2050 , feeding a rapidly growing human population will mean adopting a sustainable food production approach that can run indefinitely with minimized impacts on the environment, animal welfare and human health.

It is therefore necessary to incorporate in these highly productive agricultural systems' biotechnological tools that are compatible with the amount of nutrients required for each specific crop. The global market for bio-inoculants, which is growing at an estimated rate of $10 \%$ per annum [7], was valued at $\$ 440$ million in 2012 and is expected to reach $\$ 1,295$ million by 2020 [8].

Much information exists concerning microorganisms in plant nutrition, especially with regard to bacteria and arbuscular mycorrhizal fungi (AMF), in the case of commercial products. Despite this, it is still very difficult to determine their effectiveness in promoting plant growth and crop yields, when in most cases the mechanisms responsible for these beneficial effects are unknown and quality control procedures within the industry and accepted standards to allow product comparison, etc. are generally lacking [9]. The aim of this contribution was to show the benefits of the application of Glomus iranicum var. tenuihypharum on plant physiology, nutrition and productivity under several farming systems and covering several commercial crops, such as table grapes and vegetables. The impact of its application in different countries was also studied.

\section{Selection Criteria for Choosing an Arbuscular Mycorrhizal (AM) Strain}

The term "mycorrhiza" is derived from the Greek myco-(fungus) and rhiza (root). Mycorrhizae are associated with plant roots through an extensive (extraradical) network of hyphae in the soil, which acts as an extension of the plant's root system.

The efficient exchange of nutrients (sucrose to the fungus and N/P and other nutrients to the plant) is mediated via specialized structures within the roots (e.g., intracellular arbuscules in AMF). AM and ectomycorrhizae are the most widespread and ecologically important types of mycorrhiza and the only ones commercially exploited in agriculture and forestry.

However, major advances in our knowledge of mycorrhizal symbiosis have thrown light on their activity in plant nutrition. Just as the ecological functions of this symbiosis are much better understood, the biodiversity and evolution of the same are no longer a black box, and the genomes of a wide range of mycorrhizal fungi have been sequenced. At the same time, molecular interactions responsible for the symbiosis are starting to be revealed [10].

The success of AM symbiosis depends not only on the plant and fungal genotypes, but also on the conditions of the environment. The functional specificity that exists between plants and AMF has been well documented [11-13]. The soil environment is known to exert a strong selection pressure on AMF $[14,15]$, but the influence of the soil on $\mathrm{AM}$ genotypes is less well understood [16].

The soil is an important key to the effectiveness of AMF, because it not only provides mineral nutrients to the fungi, but also constitutes the chemical, physical and environmental platform, where both 
associates live. Liming the soil was seen to decrease root colonization by Acaulospora laevis, but to increase root colonization by G. invermaium [17], confirming that different $\mathrm{AM}$ species have different soil $\mathrm{pH}$ optima. The adaptation of AMF to specific soil $\mathrm{pH}$ was revealed by AM strains that only existed within a given range of soil $\mathrm{pH}$ values [18]. It seems, then, that AM strains may survive and function well only within a certain range of soil environmental conditions [19].

Several studies have shown that plant responses to inoculation vary in different soils [20-23], and until now, this lack of consistency has hindered the efficient use of AM inoculants in plant production. AM strains must not only be highly effective, but also be able to function in the soil environment where they are introduced. Selecting strains based on target soil properties may be the key to consistency in the effect of AM inoculants.

Both nutrient level and the nutrient balance are important factors influencing $\mathrm{AM}$ symbiotic development and function [24]. A nutrient imbalance may alter the function of indigenous AMF strains, and soils with an altered nutrient balance may benefit from the introduction of adapted AM strains.

Although AM symbiosis constitutes the most important microbial association in agronomy and has evolved in most terrestrial environments as an efficient system of nutrient uptake in plants [25], factors, such as type of soil, high and unbalanced fertilizations levels, and the incorrect selection of strains [26] will exert a marked influence on the success of the implantation of this technology [27], making it necessary to choose strains according to the type of soil.

\section{Performance of AM Inoculants}

There are two types of AM inoculants, those containing a mixture of spores and propagules propagated with a host plant on an inert carrier in containers or beds in field conditions [28], and those produced in vitro with transformed carrot root organ cultures as host, mainly the strain Rhizophagus irregularis or intraradices.

The success of commercial AM inoculants may be judged according to economic gain, either through improved yields or reduced applications of inorganic fertilizer, or both. They should not be viewed as a replacement for inorganic fertilizers, but as a potential component of an integrated nutrient management strategy that enhanced soil nutrient acquisition [9].

Some of the peer-reviewed publications that report AM crop application results are listed in Table 1.

Table 1 Peer-reviewed publications that have used commercially available AM products. Species names are as reported within each paper (AMF, formerly known as Glomus spp., have recently been renamed).

\begin{tabular}{|c|c|c|c|c|c|c|}
\hline Product & Crop & Field/lab & Microorganisms & Results & Application rate & References \\
\hline $\begin{array}{l}\text { Mycormax. JH Biotech } \\
\text { Inc., Ventura, U.S. }\end{array}$ & Zea mays & $\mathrm{Lab}$ & 2 Glomus species +5 EM & $\begin{array}{l}<5 \% \text { of root } \\
\text { colonization; } \\
\text { increased DMY }\end{array}$ & $1.2 \mathrm{~g} / \mathrm{L}$ soil & [29] \\
\hline $\begin{array}{l}\text { BEI Bio Organics, Santa } \\
\text { Maria, U.S. }\end{array}$ & Zea mays & $\mathrm{Lab}$ & $\begin{array}{l}6 \text { Glomus species }+1 \\
\text { Gigaspora }+1 \text { Paraglomus }\end{array}$ & $\begin{array}{l}<5 \% \text { root } \\
\text { colonization; } \\
\text { no increased DMY }\end{array}$ & $1.8 \mathrm{~g} / \mathrm{L}$ soil & [29] \\
\hline $\begin{array}{l}\text { AgBio Endos, AgBio } \\
\text { Inc., Westminster, U.S. }\end{array}$ & Zea mays & $\mathrm{Lab}$ & $\begin{array}{l}6 \text { Glomus species }+1 \\
\text { Gigaspora }\end{array}$ & $\begin{array}{l}<5 \% \text { root } \\
\text { colonization; } \\
\text { no increased DMY }\end{array}$ & $3.0 \mathrm{~g} / \mathrm{L}$ soil & [29] \\
\hline $\begin{array}{l}\text { AM 120. Reforestation } \\
\text { Technologies Int., U.S. }\end{array}$ & Zea mays & $\mathrm{Lab}$ & 3 Glomus species & $\begin{array}{l}<5 \% \text { of root } \\
\text { colonization; } \\
\text { increased DMY }\end{array}$ & $3.0 \mathrm{~g} / \mathrm{L}$ soil & [29] \\
\hline $\begin{array}{l}\text { BioGrow Endo. } \\
\text { Mycorrhizal } \\
\text { Applications Inc., U.S. }\end{array}$ & Zea mays & $\mathrm{Lab}$ & $\begin{array}{l}3 \text { Glomus species }+1 \\
\text { Trichoderma }\end{array}$ & $\begin{array}{l}<5 \% \text { of root } \\
\text { colonization; } \\
\text { increased DMY }\end{array}$ & $3.0 \mathrm{~g} / \mathrm{L}$ soil & [29] \\
\hline $\begin{array}{l}\text { EcoMic-Micofert } \\
\text { Research Centres, Cuba }\end{array}$ & $\begin{array}{l}\text { Coffee and } \\
\text { horticultural } \\
\text { crops }\end{array}$ & Field & $\begin{array}{l}\text { G. intraradices, G. } \\
\text { fasciculatum, G. mosseae, } \\
\text { G. etunicatum, Paraglomus } \\
\text { ocultum }\end{array}$ & $\begin{array}{l}\text { Increased DMY } \\
\text { according soil type }\end{array}$ & $4-5 \mathrm{~kg} / \mathrm{ha}$ & {$[30]$} \\
\hline
\end{tabular}


(Table 1 continued)

\begin{tabular}{|c|c|c|c|c|c|c|}
\hline Product & Crop & Field/lab & Microorganisms & Results & Application rate & References \\
\hline $\begin{array}{l}\text { Mycor Tree Root Dip } \\
\text { Plant Healthcare Inc., } \\
\text { U.S. }\end{array}$ & Zea mays & $\mathrm{Lab}$ & 5 Ecto/Endomycorrhiza & $\begin{array}{l}<5 \% \text { root } \\
\text { colonization; } \\
\text { no increased DMY }\end{array}$ & $\begin{array}{l}\text { Mix with water } \\
\text { (not specified) }\end{array}$ & [29] \\
\hline $\begin{array}{l}\text { MYKE PRO SG2 } \\
\text { Premier Tech, Canada }\end{array}$ & Zea mays & $\mathrm{Lab}$ & G. intraradices & No increased DMY & $7.5 \mathrm{~kg} / \mathrm{ha}$ & {$[31]$} \\
\hline $\begin{array}{l}\text { MYKE PRO SG2 } \\
\text { Premier Tech, Canada }\end{array}$ & $\begin{array}{l}\text { Solanum } \\
\text { tuberosum }\end{array}$ & Field & G. intraradices & Increased DMY & $15 \mathrm{~cm} /$ plant & {$[32]$} \\
\hline $\begin{array}{l}\text { Aegis Italpollina, Rivoli } \\
\text { Veronese, Italy }\end{array}$ & Zea mays & Field & G. intraradices & No increased DMY & $25 \mathrm{~kg} / \mathrm{ha}$ & {$[33]$} \\
\hline MycoApply Endo & Zea mays & Field & G. intraradices & No increased DMY & $10 \mathrm{~g} /$ pot & {$[34]$} \\
\hline VAM 80 & Zea mays & Field & G. intraradices & No increased DMY & 1 tablespoon/pot & {$[34]$} \\
\hline Ascend PB & Zea mays & Field & G. intraradices & No increased DMY & $1 \mathrm{~g} /$ pot & {$[34]$} \\
\hline NTC & Zea mays & Field & G. intraradices & No increased DMY & $30 \mathrm{~mL} /$ pot & {$[34]$} \\
\hline $\begin{array}{l}\text { MycoGrowth } \\
\text { Symborg, Spain }\end{array}$ & Tomato & Field & $\begin{array}{l}\text { G. iranicum var. } \\
\text { tenuihypharum }\end{array}$ & $\begin{array}{l}\text { Increased DMY and } \\
\text { yield }\end{array}$ & $3 \mathrm{~kg} / \mathrm{ha}$ & {$[35]$} \\
\hline $\begin{array}{l}\text { MycoGrowth } \\
\text { Symborg, Spain }\end{array}$ & Lettuce & Field & $\begin{array}{l}\text { G. iranicum var. } \\
\text { tenuihypharum }\end{array}$ & $\begin{array}{l}\text { Increased DMY and } \\
\text { yield }\end{array}$ & $3 \mathrm{~kg} / \mathrm{ha}$ & {$[36]$} \\
\hline $\begin{array}{l}\text { MycoGrowth } \\
\text { Symborg, Spain }\end{array}$ & Grape & Field & $\begin{array}{l}\text { G. iranicum var. } \\
\text { tenuihypharum }\end{array}$ & $\begin{array}{l}\text { Increased DMY and } \\
\text { yield }\end{array}$ & $3 \mathrm{~kg} / \mathrm{ha}$ & {$[37]$} \\
\hline $\begin{array}{l}\text { Resid } \\
\text { Symborg, Spain }\end{array}$ & Rice & Field & $\begin{array}{l}\text { G. iranicum var. } \\
\text { tenuihypharum }\end{array}$ & $\begin{array}{l}\text { Increased DMY and } \\
\text { yield }\end{array}$ & $3 \mathrm{~kg} / \mathrm{ha}$ & {$[38]$} \\
\hline $\begin{array}{l}\text { MycoGrowth } \\
\text { Symborg, Spain }\end{array}$ & $\begin{array}{l}\text { Ornamental } \\
\text { plant }\end{array}$ & Field & $\begin{array}{l}\text { G. iranicum var. } \\
\text { tenuihypharum }\end{array}$ & $\begin{array}{l}\text { Increased DMY and } \\
\text { yield }\end{array}$ & $3 \mathrm{~kg} / \mathrm{ha}$ & [39] \\
\hline $\begin{array}{l}\text { MycoGrowth } \\
\text { Symborg, Spain }\end{array}$ & Strawberry & Field & $\begin{array}{l}\text { G. iranicum var. } \\
\text { tenuihypharum }\end{array}$ & $\begin{array}{l}\text { Increasing firm } \\
\text { depend of the variety }\end{array}$ & $3 \mathrm{~kg} / \mathrm{ha}$ & {$[40]$} \\
\hline
\end{tabular}

$\mathrm{DMY}=$ dry matter yield.

Some authors [29] found the number of positive and negative responses to the inoculation of maize with different mycorrhizal inoculants containing different fungal species to be the same. Hart and Forsythe [41] found that a single inoculation with $R$. irregularis increased the host (Allium porrum L. and Plantago lanceolata L.) nutrient content, irrespective of soil nutrient status, in contrast to mixed AM treatments. Similarly, using soil with high levels of phosphorus (P), Cozzolino et al. [32] recorded a significant increase in total fresh weight of a potato crop using the single strain (Mike Pro SG2) ( $R$. irregularis).

For their part, using different mycorrhizal products based on $R$. intraradices/R. irregularis, Corkidi et al. [34] always achieved negative results in field trials of maize cultivation, using different inoculation dosages. However, lettuce plants inoculated with G. iranicum var. tenuihypahrum showed higher nitrogen $(\mathrm{N})$, calcium $(\mathrm{Ca})$ and potassium $(\mathrm{K})$ uptake from saline and non-saline substrates, while the uptake of sodium
(Na) was reduced [36]. Under highly saline field conditions, better growth of the ornamental plant Viburnum tinus (Laurustinus) was observed [39]. Under greenhouse conditions, tomato plants inoculated with $G$. iranicum var. tenuihypharum showed improved water use efficiency (WUE), probably the result of a controlled rate of transpiration, and a higher rate of net photosynthesis. In addition, a close relationship was found between the respiratory activity of AMF and the rate of net photosynthesis, leaf $\mathrm{N}, \mathrm{P}, \mathrm{Fe}$ and $\mathrm{K}$ concentrations, and fruit yield. As a result, the overall performance (growth, nutrition and yield) of plants cultivated under an intensive fertigation regime improved [35]. The species has a broad host spectrum covering both monocots, such as Sorghum spp., and dicots, such as Viburnum spp., Lactuca spp. [36, 39]. In strawberry, a positive influence was observed on production [40] and the levels of anthocyans in the variety Fortuna, but not in other varieties.

The efficacy of AMF, when used in inoculants, is 
also influenced by numerous soil, crop and environmental factors, including crop species compatibility, size and effectiveness of indigenous microbial populations, soil fertility and management [42]. Despite the successful laboratory results obtained with certain strains of AMF, studies agree that scale-up of their use for agriculture has been slow, probably due to the relative ineffectiveness of the inoculation process [27], or other factors, such as the technical difficulty involved in their application, the degree of soil compatibility [19] and field carrying capacity [35], etc..

In light of the above results, our objective was to select an AM species that could have a stable positive effect, regardless of external conditions, when used as a biological inoculant in intensive agriculture. In this context, the main criteria taken in account were the soil environment and the adaptation of the AMF to a specific range of soil $\mathrm{pH}$ levels $[18,19]$. The species chosen would have to show constant results in the special conditions required by different intensive agriculture systems and crop families.

\section{G. iranicum var. tenuihypharum: A Study Case}

The strain G. iranicum var. tenuihypharum was previously isolated from a hydromorphic and highly compacted sodium saline soil classified as Solonetz Gley type. Some chemical properties are presented in Table 2. As can be seen, it is a very alkaline soil $(\mathrm{pH}$
$\mathrm{H}_{2} \mathrm{O}$ 9.5), with high concentrations of $\mathrm{Ca}, \mathrm{Na}$ and $\mathrm{Mg}$, low $\mathrm{C} / \mathrm{N}$ ratio and low organic matter level.

Strain Morphology.

Sporocarps: none observed.

Spores: Small spores up to 65-70 $\mu \mathrm{m}$ diameter, usually aggregated in loose to compact clusters. The spore wall consists of two or three layers. The spore wall layer one, forming the spore surface, is mucilaginous, short-lived and stains in Melzer's reagent or is type unique (not divided into sublayers), permanent and does not react in Melzer's reagent (it is not present in Fig. 1). The middle layer $\left(\mathrm{SWL}_{2}\right)$ is permanent, 0.5-2.0 $\mu \mathrm{m}$ thick, and the inner layer $\left(\mathrm{SWL}_{3}\right)$ laminar $(0.5-1.5 \mu \mathrm{m})$. Spore contents are pale and guttulate (Fig. 1).

Subtending hyphae are hyaline to pale ochraceous, straight or undulating 2.5-4.5 $\mu \mathrm{m}$ in diameter (mean $3.0 \mu \mathrm{m})$, with a cylindrical to slightly funnel shape continuous with spore wall layers; pore open in mature spores.

Germination structure: Germ tube re-grows through the hyphal attachment, forming vesicular-arbuscular mycorrhizae. Extraradical mycelium is abundant. Older spores look somewhat shaggy. $\mathrm{SWL}_{1}$ exhibits a dextrinoid reaction, when stained with Melzer's reagent, giving young spores a brownish red colour. $\mathrm{SWL}_{2}$ is permanent, 0.5-2.0 $\mu \mathrm{m}$ thick; $\mathrm{SWL}_{3}$ laminar $(0.5-1.5 \mu \mathrm{m})$. Spore contents are pale, guttulate (Fig. 1).

Table 2 Some chemical properties of the Solonetz Gley soil where G. iranicum var. tenuihypharum was isolated.

\begin{tabular}{ll}
\hline Parameters & Concentration \\
\hline $\mathrm{pH}\left(\mathrm{H}_{2} \mathrm{O}\right)$ & 9.5 \\
$\mathrm{pH}(\mathrm{KOH})$ & 10.1 \\
Organic matter $(\%)$ & 0.8 \\
$\mathrm{~N}(\%)$ & 0.2 \\
$\mathrm{C} / \mathrm{N}$ ratio & 6.5 \\
$\mathrm{Calcium}$ carbonates $(\%)$ & 12.0 \\
$\mathrm{Ca}(\mathrm{ppm})$ & $5,809.6$ \\
$\mathrm{Na}(\mathrm{ppm})$ & $1,829.4$ \\
$\mathrm{Mg}(\mathrm{ppm})$ & $2,967.04$ \\
\hline
\end{tabular}



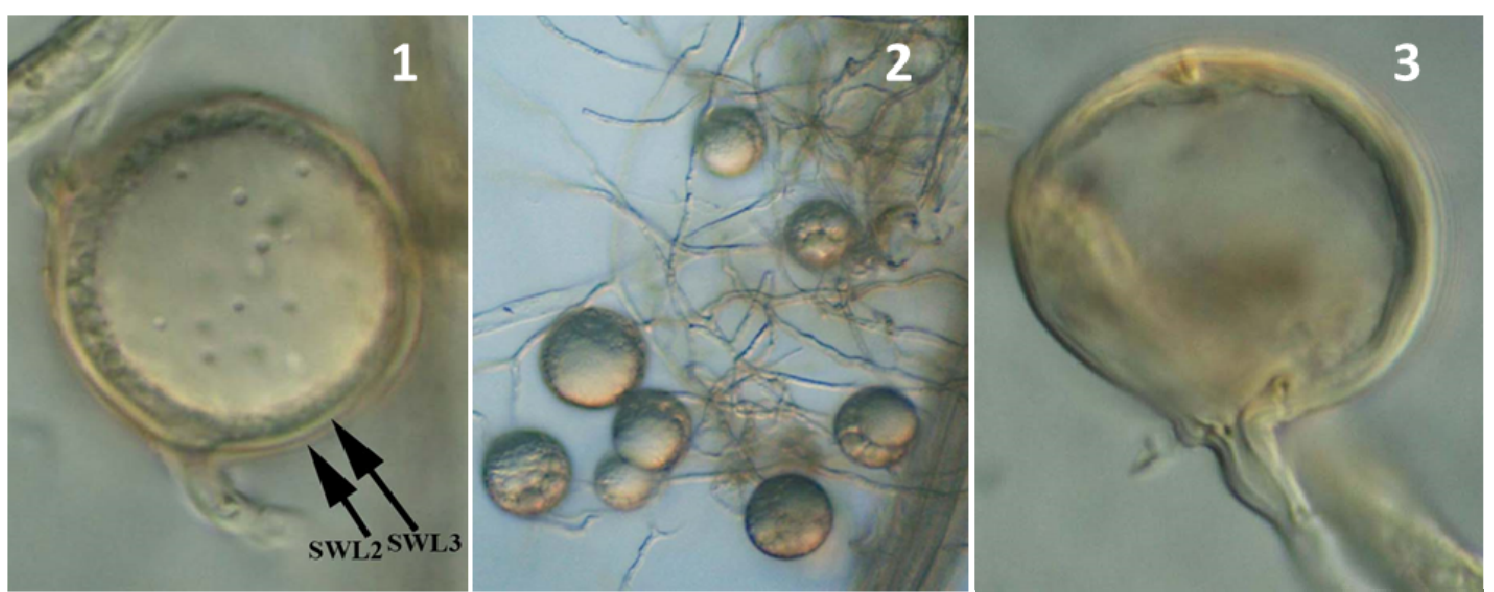

Fig. 1 Light micrographs of spores of G. iranicum var. tenuihypharum. (1) Mature spore; spore wall layers $\mathrm{SWL}_{2}$ and $S W L_{3}$ are visible (arrows); (2) typical, loose cluster of spores; (3) open pore towards the subtending hypha.

4.1 Effect of G. iranicum var. tenuihypharum and Other AM Species on Lettuce Crop Production under Standard Fertilization Program

The aim for this study was to determine the effectiveness of $G$. iranicum var. tenuihypharum compared with other strains of AMF in lettuce (Lactuca sativa L., variety "Capitata") grown under a standard fertilization program.

4.1.1 Material and Methods

\subsubsection{Experiment Design}

This study was conducted at the experimental farm of the Centro de Edafología y Biología Aplicada del Segura (CEBAS-CSIC) in Murcia, Spain $\left(38^{\circ} 07^{\prime} 18^{\prime \prime} \mathrm{N}\right.$, $1^{\circ} 13^{\prime} 15^{\prime \prime} \quad$ W). The experiment lasted $90 \mathrm{~d}$ (January-May 2015) and was carried out under controlled conditions in a greenhouse equipped with a cooling system with a relative humidity of $55 \%-65 \%$, day/night temperatures of $25{ }^{\circ} \mathrm{C} / 12{ }^{\circ} \mathrm{C}$, and a $10 \mathrm{~h}$ photoperiod at a maximum photosynthetic photon flux density (PPFD) of 1,500 $\mu \mathrm{mol}$, measured using an external light meter (LI-Quantum Q-40211, LI-COR Inc., Lincoln, NE, USA) during the gas exchange measurements.

An experimental design consists of four treatments, 10 pots per treatment and one plant per pot were used. A total of 40 pots, each five liters of substrate composed of a 3:2:1 (v/v/v) mix of calcareous soil:sand:vermiculite was used in the experiment. The substrate had a $\mathrm{pH}$ of 7.1 , with $1.7 \%(\mathrm{w} / \mathrm{w})$ organic matter, $0.9 \%(\mathrm{w} / \mathrm{w})$ total organic carbon, $0.1 \%(\mathrm{w} / \mathrm{w})$ total $\mathrm{N}$ and $196.6 \mathrm{mg} / \mathrm{kg}$ available $\mathrm{P}$. The substrate was not sterilized in order to simulate the real-life scenario of compatibility and competition between native and inoculated AMF.

The studied treatments were the AMF types and a non-treated control. Three species of AMF were used in this study: F. mosseae (Nicholson \& Gerdeman) Gerdeman \& Trappe, R. irregularis (N.C. Schenck \& G.S. Sm., 1982) and G. iranicum var. tenuihypharum var. nova from Symborg company.

An irrigation system was installed; each pot was fitted with one pressure-compensated emitter per plant at a flow rate $2 \mathrm{~L} / \mathrm{h}$ and a device for homogenizing water delivery over the entire surface of the substrate. The lettuce seedlings (L. sativa L.) of variety Capitata and iceberg type were transplanted in January-March 2015. One week after transplanting, an AM powder formulation was delivered through the irrigation system at doses equivalent to $3 \mathrm{~kg} / \mathrm{ha}$ of $F$. mosseae with a propagule concentration of 125 propagules $/ \mathrm{g}, R$. irregularis at 140 propagules/g and G. iranicum var. tenuihypharum at 120 propagules/g, according to the most probable number test, as described by Porte [43].

Each treatment received the same standard fertilization. Fertilization consisted of a granulate fertilizer that contained: N 7\%, P 4\%, K 6\%, Ca $25 \%$ and sulfur (S) $2 \%$, mixed with the substrate at the 
equivalent of $500 \mathrm{~kg} / \mathrm{ha}$ before filling the pots and, after transplanting, a fertirrigation solution of $\mathrm{pH} 7.90$, electric conductivity $2,106 \mathrm{mmhos} / \mathrm{cm}$, and total soluble solids $0.93 \mathrm{~g} / \mathrm{L}, \mathrm{KNO}_{3} 15,000 \mathrm{~g}, \mathrm{Ca}\left(\mathrm{NO}_{3}\right)_{2}$ $1,000 \mathrm{~g}, \mathrm{H}_{3} \mathrm{PO}_{4} 508 \mathrm{~g}, \mathrm{HNO}_{3} 452 \mathrm{~g}$ were applied twice a week during the assay. Water irrigation was applied equally in all treatments (three times per week).

\subsubsection{Symbiotic Activity}

The percentage of mycorrhizal colonization was calculated following the classic gridline intersect method [19], after staining the roots with the method described by Phillips [44], which consisted of clearing washed roots $(200 \mathrm{~g})$ in $10 \% \mathrm{KOH}, 20 \mathrm{~min}$ at $90{ }^{\circ} \mathrm{C}$ in water bath and after staining with $0.05 \%$ trypan blue in lactic acid $(\mathrm{v} / \mathrm{v})$, for 15 min, keeping the same conditions mentioned before. Extramatrical mycelium was measured by estimating the visual presence in a given area [19]. Easily extractable glomalin was detected by the method described by Wright et al. [45].

\subsubsection{Biomass Production}

Lettuce growth (shoot fresh weight (SFW), shoot dry weight (SDW), root fresh weight (RFW), root dry weight (RDW) and shoot diameter (SD)) were analysed at each sampling time according to: (1) Regulation No. 771/2009 of the European Union Commission, (2) the indications proposed by Ryder [46], and (3) personal communication with landowners. Dry weights (DW) were measured after drying in a forced hot-air oven at $80{ }^{\circ} \mathrm{C}$ until a constant weight was reached (approximately $48 \mathrm{~h}$ ).

The gas exchange parameters (net photosynthesis (A) and stomatal conductance $\left(g_{s}\right)$ ) were measured in 10 plants/treatment, using a LICOR LI-6400 Portable Photosynthesis System (LI-COR Inc., Lincoln, NE, USA model. LI-6400). All measurements were performed at solar noon and twice during the assay period of $75 \mathrm{~d}$. WUE was determined from the $A / g_{s}$ ratio.

Chlorophyll (in SPAD units) was measured in 10 plants twice (days 40 and 75) during the assay, using a portable meter (chlorophyll meter SPAD-502, Konica Minolta), which makes instantaneous and non-destructive measurements of the relative chlorophyll index.

The ions content of leaves was obtained by the ICP-OES technique (Iris Intrepid II XDL, OribaSci.) $75 \mathrm{~d}$ after transplanting. The ions measured were $\mathrm{N}, \mathrm{P}$, $\mathrm{K}$ and $\mathrm{Ca}$, and the trace elements were manganese $(\mathrm{Mn})$, iron $(\mathrm{Fe})$ and zinc $(\mathrm{Zn})$.

\subsubsection{Data Analysis}

Data were analyzed using a one-way analysis of variance, using SPSS V21 for Windows to detect any significant differences between the parameters measured. In addition, when differences were significant, Tukey's range test at the $95 \%$ confidence level was carried out for a comparison between treatments. Percentage values of root colonization were arcsine (square root $(\mathrm{X})$ ) transformed before statistical analysis.

\subsubsection{Results}

\subsubsection{Mycorrhizal Activity}

Table 3 showed the mycorrhizal activity of the three strains under study. As can be seen, the AMF led to higher values of every variable studied, compared with untreated plants. The highest colonization values (78\%) were obtained with $G$. iranicum var. tenuihypharum var. nova strain, while $F$. mosseae and $R$. irregularis attained much lower values $(21.24 \%$ and $24.0 \%)$, although in all cases the difference was statistically significant compared with untreated plants.

Surprisingly, extramatrical mycelium showed notable differences among the types of fungal species. The species isolated from the sodium-saline soil ( $G$. iranicum var. tenuihypharum var. nova) showed the highest values of external mycelium, $850 \mathrm{mg} / \mathrm{kg}$ soil, followed by $R$. irregularis and both values were higher than that obtained with the untreated plants. In the case of F. mosseae, a low level of mycelium was noted (143 mg/kg soil), which were comparable with the obtained with the native strains $(122.2 \mathrm{mg} / \mathrm{kg}$ soil 
in the untreated plants). Similar behavior was observed in the case of glomaline excretion, $G$. iranicum var. tenuihypharum var. again being the specie that excreted more protein into the medium than the other two species (Table 3).

\subsubsection{Physiology Activity}

Table 4 showed the measurements of SPAD, $A, g_{s}$ and WUE $\left(A / g_{s}\right)$ at 75 d. $G$. iranicum var. tenuihypharum var. nova reached the highest $A$ and SPAD values, following the same pattern as above. The same species, in contrast, exhibited the lowest $g_{s}$ value (120 $\mathrm{mmol} \mathrm{H}_{2} \mathrm{O} / \mathrm{m}^{2} / \mathrm{s}$ ) - even lower than that observed with untreated plants. However, this species had the best WUE (106.33 $\left.\mu \mathrm{mol} \mathrm{CO}_{2} / \mathrm{mol} \mathrm{H}_{2} \mathrm{O}\right)$, significantly higher than that observed for the other species, which did not present significant differences between them.

The other strains displayed lower physiological activity than $G$. iranicum var. tenuihypharum var. nova and, although they had higher photosynthetic activity at $75 \mathrm{~d}$, it was at the expense of increased stomatal conductivity, meaning a less efficient use of water.

The untreated plants reached a WUE value of 67.76, which was not significantly different from the values reached with the other two species of AMF, $F$. mosseae and $R$. irregularis (67.07 and 65.92). The fact that these values are lower than in the control treatment reflects a photosynthetic mismatch, possibly derived from a symbiotic relationship not suitable for this stage of the crop.

Obviously, this analysis of the physiological activity of the evaluated plants is closely related to productivity and the nutritional levels achieved in plants treated with AMF.

\subsubsection{Biomass Production}

Tables 5 and 6 showed the leaf and root fresh dry weights reached in the different treatments at harvest, as well as nutritional elements at $75 \mathrm{~d}$ of cultivation.

The analysis of shoot and root biomass illustrates the positive effect of the application of AMF. Due to its proper mycorrhizal functioning and the physiological benefits it provided to the treated plants, G. iranicum var. tenuihypharum var. nova induced the highest biomass values measured as fresh and dry weight (Table 5), while the other species of arbuscular mycorrhizae studied did not produce any significant increase in biomass production.

Table 3 Extramatrical mycelium (mg/kg soil), mycorrhizal colonization (\%) and easily extractable Glomaline concentration (mg/g soil) in lettuce plants inoculated with F. mosseae, G. iranicum var. tenuihypharum and R. irregularis and untreated after 75 d under a conventional fertilization program.

\begin{tabular}{lllc}
\hline Treatments & $\begin{array}{l}\text { Extramatrical mycelium } \\
(\mathrm{mg} / \mathrm{kg} \text { soil) }\end{array}$ & Mycorrhizal colonization (\%) & Glomaline (mg/g soil) \\
\hline F. m & $143.0 \pm 17.8$ & $21.25 \pm 1.50$ & $133.0 \pm 2.1$ \\
G.i.v.t & $850.0 \pm 19.9$ & $78.7 \pm 1.63$ & $467.1 \pm 5.6$ \\
R. i. & $232.0 \pm 13.9$ & $24.3 \pm 6.70$ & $323.3 \pm 5.6$ \\
C & $122.2 \pm 13.2$ & $12.3 \pm 1.00$ & $90.00 \pm 1.7$ \\
\hline
\end{tabular}

F. m: F. mosseae; G.i.v.t: G. iranicum var. tenuihypharum; R. i: R. irregularis; C: untreated.

Table 4 SPAD, $A\left(\mu \mathrm{mol} \mathrm{CO} / \mathrm{m}^{2} / \mathrm{s}\right), g_{s}\left(\mathrm{mmol} \mathrm{H}_{2} \mathrm{O} / \mathrm{m}^{2} / \mathrm{s}\right)$ and WUE $\left(\mu \mathrm{mol} \mathrm{CO} \mathrm{CO}_{2} / \mathrm{mol} \mathrm{H}_{2} \mathrm{O}\right)$ in lettuce plants inoculated with $\mathrm{F}$. mosseae, $G$. iranicum var. tenuihypharum and $R$. irregularis and untreated after $75 \mathrm{~d}$ with a standard fertilization program.

\begin{tabular}{lllll}
\hline Treatments & SPAD & $A$ & $g_{s}$ & $\begin{array}{l}\text { WUE } \\
\left(A / g_{s}\right)\end{array}$ \\
\hline F. m & $20.2^{\mathrm{b}}$ & $9.39^{\mathrm{b}}$ & $140^{\mathrm{a}}$ & $67.07^{\mathrm{b}}$ \\
G.i.v.t & $28.1^{\mathrm{a}}$ & $12.76^{\mathrm{a}}$ & $120^{\mathrm{b}}$ & $106.33^{\mathrm{a}}$ \\
R. i. & $19.0^{\mathrm{c}}$ & $9.23^{\mathrm{b}}$ & $140^{\mathrm{a}}$ & $65.92^{\mathrm{b}}$ \\
C & $19.1^{\mathrm{c}}$ & $8.47^{\mathrm{b}}$ & $125^{\mathrm{b}}$ & $67.76^{\mathrm{b}}$ \\
\hline
\end{tabular}

Different letters in the same column correspond to significantly different values. F. m: F. mosseae; G.i.v.t: G. iranicum var. tenuihypharum; R. i: R. irregularis; C: untreated. 
The analysis of foliar nutrient concentrations at $75 \mathrm{~d}$ of cultivation confirmed the results obtained for the other variables studied (Table 6). Significant differences were found in most of the elements between the studied treatments except the $\mathrm{K}$ and $\mathrm{Zn}$ contents. Once again, the highest values were recorded in the treatments that showed the greatest development as regard biomass and physiological activity, i.e., with $G$. iranicum var. tenuihypharum var. nova species.

It is also important to highlight the high values of the trace elements Fe and Mn, which are essential for photosynthesis and growth activity in general, measured in plants treated with G. iranicum var. tenuihypharum var. nova, which differed significantly from the rest of the plants, treated or not with AMF.

For the other species of mycorrhizal fungi and the untreated plants, the concentrations of nutritional elements did not show any significant differences between them, reflecting the low absorption of these elements under conditions of intensive nutrient fertirrigation.

\subsubsection{Discussion}

Although irrigation water with a high nutrient content can reduce the colonization capacity, spore germination and the growth of fungal hyphae [47], some AMF can be used under intensive agriculture conditions. The results showed that AMF symbiosis was well established on lettuce roots and that the colonization rates were in close agreement with those observed in other studies [48, 49].

The increased biomass (SDW) observed in plants inoculated with $G$. iranicum var. tenuihypharum reflected the high degree of mycorrhization observed in those plants [50]. Mycorrhizal symbiosis in lettuce root might have favored the absorption of water and nutrients [51], increasing biomass. The high values of root development found in the most successful association suggested that the combination probably induced the root system to improve hydraulic conductivity [52] and take more water from the soil.

The higher $\mathrm{N}$ concentration detected in plants treated with $G$. iranicum var. tenuihypharum can be mainly attributed to: (1) the high $\mathrm{NO}^{3-}$ concentration in the nutrient solution and (2) an increase in the nutrient absorption rate, which would improve the nutritional status of the lettuce plants because of a more developed root system as a result of the mycorrhizal symbiosis [53].

Table 5 Biomass of shoot and root expressed as SFW, SDW, RFW and RDW in untreated lettuce plants and plants inoculated with F. mosseae, G. iranicum var. tenuihypharum and $R$. irregularis $75 \mathrm{~d}$ after planting and exposed to a conventional fertilization program.

\begin{tabular}{lllll}
\hline Treatments & SFW $(\mathrm{g})$ & SDW $(\mathrm{g})$ & RFW $(\mathrm{g})$ & RDW $(\mathrm{g})$ \\
\hline F. m & $600.42 \pm 0.33$ & $9.18 \pm 1.50$ & $122.28 \pm 1.60$ & $1.70 \pm 1.70$ \\
G.i.v.t & $800.03 \pm 0.62$ & $17.19 \pm 0.25$ & $232.13 \pm 5.43$ & $2.89 \pm 0.44$ \\
R. i. & $613.68 \pm 4.60$ & $10.71 \pm 2.30$ & $162.83 \pm 9.62$ & $1.60 \pm 0.33$ \\
C & $678.26 \pm 3.73$ & $9.12 \pm 2.45$ & $179.51 \pm 3.21$ & $1.4 \pm 0.93$ \\
\hline
\end{tabular}

F. m: F. mosseae; G.i.v.t: G. iranicum var. tenuihypharum; R. i: R. irregularis; C: untreated lettuce plants.

Table 6 Concentrations of some nutritional elements (ppm) in lettuce plants inoculated with F. mosseae, G. iranicum var. tenuihypharum and $R$. irregularis and untreated plants after $75 \mathrm{~d}$ of a conventional fertilization program.

\begin{tabular}{llllllll}
\hline Treatments & $\mathrm{N}(\mathrm{ppm})$ & $\mathrm{P}(\mathrm{ppm})$ & $\mathrm{K}(\mathrm{ppm})$ & $\mathrm{Ca}(\mathrm{ppm})$ & $\mathrm{Mn}(\mathrm{ppm})$ & $\mathrm{Fe}(\mathrm{ppm})$ & $\mathrm{Zn}(\%)$ \\
\hline F. m & $2.2^{\mathrm{b}}$ & $0.12^{\mathrm{b}}$ & 5.9 & $2.3^{\mathrm{b}}$ & $130.2^{\mathrm{b}}$ & $322^{\mathrm{c}}$ & 23.4 \\
G.i.v.t & $3.0^{\mathrm{a}}$ & $0.15^{\mathrm{a}}$ & 6.5 & $3.2^{\mathrm{a}}$ & $161.4^{\mathrm{a}}$ & $650^{\mathrm{a}}$ & 44.2 \\
R. i. & $2.1^{\mathrm{b}}$ & $0.11^{\mathrm{b}}$ & 5.9 & $2.4^{\mathrm{b}}$ & $132.2^{\mathrm{b}}$ & $342^{\mathrm{c}}$ & 22.1 \\
C & $2.4^{\mathrm{b}}$ & $0.10^{\mathrm{b}}$ & 6.8 & $2.2^{\mathrm{b}}$ & $136.5^{\mathrm{b}}$ & $489^{\mathrm{b}}$ & 30.2 \\
\hline
\end{tabular}

Different letters in the same column correspond to significantly different values. F. m: F. mosseae; G.i.v.t: G. iranicum var. tenuihypharum; R. i: R. irregularis; C: untreated plants. 
Good compatibility in the AM association between the roots and mycorrhizal mycelium can increase the use of different forms of $\mathrm{N}$ by plants [54]. Indeed, Johansen et al. [55] concluded that such arbuscular external mycelium as fine rootlets can take up $\mathrm{N}$ directly from the soil solution and transfer it toward the host plant at the same time.

Hirrel and Gerdemann [56] indicated that the increased uptake of $\mathrm{P}$ by plants inoculated with AMF seems to be one of the key factors responsible for increased vegetable production. In the present experiment, it was found that $\mathrm{P}$ uptake and growth only clearly increased in the case of $G$. iranicum var. tenuihypharum, but not with the rest of the strains or untreated plants.

$\mathrm{K}$ plays an important role in stomatal movements, protein synthesis and in the response to changes in leaf water status [57], but no significant differences in these respects were observed in the present study, while the increase in $\mathrm{Ca}$ detected in plants treated with G. iranicum var. tenuihypharum agreed with the observations of Cantrell and Lindeman [58].

Mycorrhizal plants also enhance the uptake of relatively immobile metal micronutrients, such as $\mathrm{Fe}$ and $\mathrm{Zn}$ [59]. $\mathrm{Ca}, \mathrm{Mg}, \mathrm{Mn}$ and Fe were higher, and $\mathrm{P}$ was within the optimum range calculated by the diagnosis and recommendation integrated system (DRIS) and proposed by Hartz et al. [60]. Different authors suggest great variability in these optimum ranges. For instance, in the case of $\mathrm{Ca}, \mathrm{Mg}$ and $\mathrm{Mn}$, Jones et al. [61] reported different optimum ranges (Ca 1.5\%-3\%, Mg 0.36\%-0.50\% and Mn 25-250 ppm). In the case of phosphate, Hochmuth et al. [62] indicated that optimum values range between $0.25 \%$ and $0.50 \%$. Bearing in mind all these assumptions, all macro- and micronutrients were deemed to be within the optimal nutritional ranges.

A higher chlorophyll content (SPAD units) was detected in plants treated with G. iranicum var. tenuihypharum, Van den Driessche [63] detected a close relationship between some nutrients $(\mathrm{N}, \mathrm{Mn}$ and
$\mathrm{Fe}$ ) and chlorophyll, and reported that an increase in these nutrients could lead to a stimulation of the synthesis of chlorophyll and hence the photosynthetic capacity. In this sense, the higher concentration of $\mathrm{N}$ and $\mathrm{Fe}$ measured in the plants could be, to a certain extent, related to the detected increase in $A$ [64].

Stable transpiration rates $\left(g_{s}\right)$ and the increased levels of $A$, associated with mycorrhizal plants significantly increase WUE [47]. In this study, the plants treated with G. iranicum var. tenuihypharum had significantly lower transpiration rates, even below those of untreated plants, but higher $A$ levels and WUE. These three positive effects, $A, g_{s}$ and WUE, may also have accounted for the enhanced plant growth of colonized plants, most probably as a result of better $\mathrm{CO}_{2}$ fixation under salt stress [49].

\subsubsection{Conclusions}

G. iranicum var. tenuihypharum var. nova was seen to be very effective under a standard fertilization program, differing not only from the controls, for which a lower response might be expected, but also compared with other species of AMF, which, in the case of some variables, led to poorer results than the control.

4.2 Effective of G. iranicum var. tenuihypharum var. nova on Table Grape Production during a Three-Year Experiment

\subsubsection{Introduction}

In South-Eastern Spain, table grapes are cultivated under intensive agriculture regimes with drip irrigation. The effectiveness of using an AM inoculant based on G. iranicum var. tenuihypharum var. nova was described here, which was specifically developed to be applied in this system.

Under natural conditions, genus Vitis is strongly dependent on the presence of AMF, and there are several studies about different grape varieties and their interaction with AMF [37, 65-67]. Here, the effect of the application of G. iranicum var. tenuihypharum var. nova on the physiology was studied, nutrient 
acquisition and yield of the table grape cultivar "Crimson" during three seasons.

\subsubsection{Materials and Methods}

The experimental design was a randomized complete design, composed of three blocks with three experimental plots per block. The standard plot was made up of 16 plants, located in four adjacent rows. The four central plants of the two middle rows were used for the different measurements and the other 12 acted as guard plants.

During the first year, the following two treatments were performed: non-inoculated Crimson grapevine plants, considered as the control treatment $\left(\mathrm{T}_{0}\right)(12$ plants) and inoculated Crimson grapevine $\left(\mathrm{T}_{1}\right)$ (24 plants). During the second and third year, half of the plot that had been inoculated during the first year was used to evaluate the persistent effect of the AMF, so the plants in this half were not re-inoculated during the second year $\left(T_{1}\right)$ (12 plants) and the plants of the other half of the plot were re-inoculated in years 2 and $3\left(\mathrm{~T}_{2}\right)$.

\subsubsection{Fungal Inoculation}

The AMF strain used G. iranicum var. tenuihypharum var. nova, was previously isolated in a sodium-saline soil with a high $\mathrm{pH}$ value of 9.5 . The inoculum at concentration of 120 propagules $/ \mathrm{g}$, calculated according to Porte [43], was supplied through the drip irrigation system (injection pump regulated at $25 \mathrm{~L} / \mathrm{h}$ ) at the beginning of the vegetative growth phase at a dose of $3 \mathrm{~kg} / \mathrm{ha}$.

It should be noted that the small size of the particles composing the product $(<100 \mu \mathrm{m})$ did not cause clogging problems in the filters, irrigation lines or emitters, and once mixed with water, the inoculum was actively located near young roots, which are the most absorbent [68].

\subsubsection{Symbiotic Development}

At the time of grape veraison, young root samples from rhizospheric soil were collected at a depth of 20-30 $\mathrm{cm}$ to assess symbiotic development. Five root samples from eight vines per treatment were used with at least four replicates per root. The percentage of mycorrhizal root colonization was estimated following the gridline intersect method [19] under a microscope (100× magnification) after clearing and staining roots [44].

\subsubsection{Stem Water Potential}

The stem water potential $\left(\psi_{\text {stem }}\right)$ was measured at noon, using a pressure chamber (Model PMS 3000; Soil Moisture Equipment Corp., USA). Measurements were carried out twice a month during the first year of the experiment but, to summarize the results, only data from the veraison stage (average of two measurements in early and late July) are shown. Before collection and taking measurements, the leaves selected were enclosed in polyethylene bags covered with aluminum foil for at least $2 \mathrm{~h}$ [69].

4.2.2.4 Net Photosynthesis (A) and Stomatal Conductance $\left(g_{s}\right)$

Instantaneous measurements of $A$ and $g_{s}$ were performed on four leaves per plot (one leaf from each inner tree), using an open gas exchange system (Li-6400; Li-Cor., Inc., Lincoln, NE, USA) with an integrated leaf chamber fluorometer (Li-6400-40; Li-Cor. Inc., Nebraska, USA). All measurements were performed on young, fully expanded leaves, at a photosynthetic photon flux density of $1,500 \mu \mathrm{mol} / \mathrm{m}^{2} / \mathrm{s}$ to ensure light saturation, with a $\mathrm{CO}_{2}$ concentration in the cuvette of $400 \mu \mathrm{mol} \mathrm{CO} \mathrm{CO}_{2} / \mathrm{mol}$ air. The sampling periods were the same as for $\psi_{\text {stem. Additionally, }}$ intrinsic WUE was determined and computed as the $\mathrm{A} / \mathrm{g}_{\mathrm{s}}$ ratio [70].

\subsubsection{Leaf-Ion Concentration}

An inductively coupled plasma ICP (ICP-ICAP 6500DUO Thermo, UK) was used for the determination of leaf macronutrients $(\mathrm{P}, \mathrm{K}, \mathrm{Ca}$ and $\mathrm{Mg}$ ) and micronutrients ( $\mathrm{Fe}, \mathrm{Zn}, \mathrm{Mn}, \mathrm{Cu}$ and $\mathrm{B}$ ). N was determined following the Dumas method [71]. In each plot, 20 leaves (five leaves from each inner tree) were collected following the criteria described for the selection of leaves used to measure $\psi_{\text {stem. The }}$ sampling periods were the same as for $\psi_{\text {stem. }}$. Ion 
concentration was compared with the macro- and micronutrient ranges determined by DRIS. Because it is difficult to obtain reliable measurements in grape, the present study used the DRIS proposed by García-Escudero et al. [72] for Tempranillo grapevine as a rough guide.

\subsubsection{Starch Concentration}

The starch concentration of grape roots was determined in February 2013, after the first two years of the experiment, using the colorimetric assay described by Zapata et al. [73], but slightly modified. Five root samples (apical and central parts) from eight grapevines per treatment were used with at least four replicates per root (apical and central parts). Then, the apical and central parts were snap frozen with liquid $\mathrm{N}$ and extracted with Milli-Q $\mathrm{H}_{2} \mathrm{O}(1 / 10$, $\mathrm{w} / \mathrm{v})$. Extracts were incubated at $100{ }^{\circ} \mathrm{C}$ for $15 \mathrm{~min}$, and then centrifuged at $12,000 \times \mathrm{g}$ for $2 \mathrm{~min}$. The supernatant was mixed with absolute ethanol (1/3, $\mathrm{v} / \mathrm{v}$ ) and centrifuged at $9,600 \times \mathrm{g}$ for $5 \mathrm{~min}$. The pellet, containing starch, was re-suspended in Milli-Q $\mathrm{H}_{2} \mathrm{O}$ and then diluted $(1 / 10, \mathrm{v} / \mathrm{v})$ if necessary (for samples containing high starch concentration). Finally, $1 \mathrm{~mL}$ of sample was mixed with $50 \mu \mathrm{L}$ of Lugol's solution (Sigma-Aldrich, Gillingham, UK) and the optical density was recorded at $595 \mathrm{~nm}$ using a Tecan-Sunrise plate reader. The starch concentration was calculated using a standard curve of pure rice starch (Sigma-Aldrich, Gillingham, UK) (0-200 $\mu \mathrm{g} / \mathrm{mL})$.

\subsubsection{Yield and Quality of Grapes}

In light of the natural stepped process of grape maturation, three cuts were performed at commercial maturity as determined primarily by color. The first cut was considered to be of the greatest commercial value. Finally, the total yield was determined as the sum of the yield weighed at each cut. To determine the quality of grapes, 100 bunches and 100 individual grapes were selected randomly from each treatment. Then, the bunch and berry weights (Radwag WLC 1.2/B1, Poland), berry diameter, firmness (Durofel
DFT 100 penetrometer, France), soluble solids concentration (ATAGO MASTER-T refractometer, USA) and acidity (Metrohm 785 DMP Titrino + automatic sample changer Metrohm 760, Switzerland) were determined. The maturity index was computed as the ratio of soluble solids concentration to acidity. Coloration of the fruits was determined using a Konica Minolta Sensing CR-10 colorimeter (Singapore) based on lightness (L; overall intensity how light or dark a colour is), angle (Hue; a dimension of color readily experienced when look at color) and chroma $(\mathrm{Ch}$; defined as the strength or dominance of the hue).

\subsubsection{Statistical Analysis}

Data were analyzed using a one-way analysis of variance, using SPSS V21 for Windows to detect any significant differences between the parameters measured. In addition, when differences were significant, Tukey's range test at the $95 \%$ confidence level was carried out for a comparison between treatments. Percentage values of root colonization were arcsine (square root $(\mathrm{X})$ ) transformed before statistical analysis.

\subsubsection{Results}

\subsubsection{Fungal Colonization and Water Status}

Table 7 showed only the percentage of root colonization for the first two years of the experiment. Natural AMF proliferation was detected in the control treatment $\left(\mathrm{T}_{0}\right)$ in both the first $(10 \%)$ and the second year $(19 \%)$. As expected, inoculated grapes presented significantly $(P<0.05)$ higher rates of colonization than the non-inoculated ones. During the first year, the mycorrhizal colonization rate compared with the control treatment was significantly $(P<0.05)$ higher $(60 \%)$.

This value was notably higher in the second year (colonization increased to $89.0 \%$ ) for $\mathrm{T}_{1}$. During this second year, not inoculating the grapevines that had only been inoculated in the first year $\left(\mathrm{T}_{2}\right)$ limited the percentage of AM root colonization (43.0\%), although a significant $(P<0.05)$ increase of $24 \%(\approx 2.3$ times 
Table 7 Percentage of root colonization and stem water potential $\left(\psi_{\text {stem }}\right.$; MPa) for the three treatments applied in this experiment.

\begin{tabular}{|c|c|c|c|c|c|}
\hline & \multicolumn{3}{|c|}{ AMF root colonization $(\%)$} & \multicolumn{2}{|c|}{ Stem water potential $(\mathrm{MPa})$} \\
\hline & Treatments & First year & Second year & First year & Second year \\
\hline \multirow[t]{3}{*}{ Crimson } & $\mathrm{T}_{0}$ & $10 \pm 2.1^{*}$ & $19 \pm 6.2^{*}$ & $-1.1 \pm 0.06$ & $-0.8 \pm 0.05$ \\
\hline & $\mathrm{T}_{1}$ & $60 \pm 21.6$ & $89 \pm 8.2$ & $-0.9 \pm 0.06$ & $-0.6 \pm 0.04$ \\
\hline & $\mathrm{T}_{2}$ & $59 \pm 19.5$ & $43 \pm 9.0$ & $-0.9 \pm 0.05$ & $-0.7 \pm 0.05$ \\
\hline
\end{tabular}

Values correspond to the average \pm S.E. of two measurements performed at the time of grape veraison (in early and late July).

${ }^{*}$ Native AMF.

Table 8 Concentration of macronutrients (N, P, K, Ca and $\mathrm{Mg}$ ) and micronutrients (Fe, $\mathrm{Zn}, \mathrm{Mn}, \mathrm{Cu}$ and $\mathrm{B})$ in table grape leaves of the Crimson variety at the time of veraison for the two-year experimental period.

\begin{tabular}{|c|c|c|c|c|c|c|c|}
\hline & & \multicolumn{2}{|c|}{ First year } & \multicolumn{3}{|c|}{ Second year } & \multirow{2}{*}{$\begin{array}{l}\text { Optimal range } \\
\text { (DRIS) }\end{array}$} \\
\hline & & $\mathrm{T}_{0}$ & $\mathrm{~T}_{1}$ & $\mathrm{~T}_{0}$ & $\mathrm{~T}_{1}$ & $\mathrm{~T}_{2}$ & \\
\hline \multirow{5}{*}{ Macronutrients $(\mathrm{g} / \mathrm{kg})$} & $\mathrm{N}$ & $32 \pm 2.1$ & $27 \pm 1.6$ & $29 \pm 1.1$ & $26 \pm 0.5$ & $28 \pm 0.7$ & $21.9-22.9$ \\
\hline & $\mathrm{P}$ & $1 \pm 0.3$ & $2 \pm 0.2$ & $2 \pm 0.2$ & $3 \pm 0.1$ & $2 \pm 0.3$ & $1.5-1.6$ \\
\hline & $\mathrm{K}$ & $12 \pm 2.1$ & $17 \pm 1.8$ & $12 \pm 0.5$ & $17 \pm 1.2$ & $13 \pm 0.7$ & $7.6-9.0$ \\
\hline & $\mathrm{Ca}$ & $40 \pm 2.5$ & $36 \pm 3.1$ & $31 \pm 1.5$ & $34 \pm 0.7$ & $29 \pm 1.8$ & $31.0-33.4$ \\
\hline & $\mathrm{Mg}$ & $4 \pm 0.4$ & $4 \pm 0.3$ & $4 \pm 0.3$ & $4 \pm 0.5$ & $4 \pm 0.4$ & $3.8-4.5$ \\
\hline \multirow{5}{*}{ Micronutrients (mg/kg) } & $\mathrm{Fe}$ & $140 \pm 7.2$ & $151 \pm 6.5$ & $150 \pm 26$ & $160 \pm 31$ & $126 \pm 24$ & $134-164$ \\
\hline & $\mathrm{Zn}$ & $12 \pm 0.5$ & $14 \pm 0.4$ & $14 \pm 2.1$ & $15 \pm 2.7$ & $14 \pm 1.9$ & $16-19$ \\
\hline & $\mathrm{Mn}$ & $43 \pm 4.2$ & $48 \pm 3.2$ & $45 \pm 6.1$ & $48 \pm 4.3$ & $46 \pm 7.2$ & $99-124$ \\
\hline & $\mathrm{Cu}$ & $39 \pm 5.3$ & $31 \pm 4.5$ & $32 \pm 2.2$ & $33 \pm 4.4$ & $33 \pm 3.8$ & $117-221$ \\
\hline & $\mathrm{B}$ & $61 \pm 2.7$ & $56 \pm 3.4$ & $58 \pm 6.5$ & $50 \pm 4.5$ & $53 \pm 3.2$ & $34-40$ \\
\hline
\end{tabular}

Values correspond to the average \pm S.E. of two measurements performed at the time of grape veraison (in early and late July). The optimal macro- and micronutrient ranges calculated for grapevine "Tempranillo" by DRIS [72] are shown.

higher) compared with $\mathrm{T}_{0}$ was still observed (Table 7).

Stem water potential $\left(\psi_{\text {stem }}\right)$ : During the first year of the experiment, AMF inoculation significantly increased $\psi_{\text {stem }}$ levels (from -1.07 MPa to -0.87 MPa). During the second year, a general increase in $\psi_{\text {stem }}$ compared to the first year was detected, but the effect of inoculation was only significant when $(P<0.05) \mathrm{T}_{1}$ $(-0.62 \mathrm{MPa})$ and $\mathrm{T}_{0}(-0.80 \mathrm{MPa})$ (Table 7) plants were compared.

\subsubsection{Leaf-Ion Concentration}

Table 8 presented the leaf-ion concentration (macro- and micronutrients) for the two-year experimental period. During the first year, inoculated grapevines showed significantly $(P<0.05)$, lower $\mathrm{N}$ but higher $\mathrm{P}$ and $\mathrm{K}$ concentrations compared to the control treatment $(\mathrm{N}=27 \mathrm{~g} / \mathrm{kg}$ vs. $32 \mathrm{~g} / \mathrm{kg}, \mathrm{P}=2 \mathrm{~g} / \mathrm{kg}$ vs. $1 \mathrm{~g} / \mathrm{kg}$ and $\mathrm{K}=17 \mathrm{~g} / \mathrm{kg}$ vs. $12 \mathrm{~g} / \mathrm{kg}$ ). In contrast, $\mathrm{Ca}$ and $\mathrm{Mg}$ remained unaffected (Table 8). A similar trend was observed during the second year, when inoculated grapevines had significantly $(P<0.05)$ reduced $\mathrm{N}$ and increased $\mathrm{P}, \mathrm{K}$ and $\mathrm{Ca}$ levels compared with the control treatment $(\mathrm{N}=26 \mathrm{~g} / \mathrm{kg}$ vs. $29 \mathrm{~g} / \mathrm{kg}, \mathrm{P}$ $=3 \mathrm{~g} / \mathrm{kg}$ vs. $2 \mathrm{~g} / \mathrm{kg}, \mathrm{K}=17 \mathrm{~g} / \mathrm{kg}$ vs. $12 \mathrm{~g} / \mathrm{kg}$ and $\mathrm{Ca}=$ $34 \mathrm{~g} / \mathrm{kg}$ vs. $31 \mathrm{~g} / \mathrm{kg}$ ). Overall, the results for $T_{2}$ were similar to those observed in $\mathrm{T}_{0}$. As regard micronutrients, no significant differences were found between treatments regardless of the year under study, and the concentrations of all micronutrients were similar in both the first and second year (Table 8).

\subsubsection{Net Photosynthesis (A) and Stomatal} Conductance $\left(g_{s}\right)$

During the first year, $A$ and $g_{s}$ seemed to be dependent on inoculation, as inoculated plants $\left(T_{1}\right)$ presented significantly $(P<0.05)$ higher values $(A=$ $8.3 \mu \mathrm{mol} \mathrm{CO} 2 / \mathrm{m}^{2} / \mathrm{s}$ and $\left.g_{\mathrm{s}}=112 \mathrm{mmol} \mathrm{H} \mathrm{O} / \mathrm{m}^{2} / \mathrm{s}\right)($ Fig. 2). Increases of $37.2 \%$ in $A$ and $34.5 \%$ in $g_{\mathrm{s}}$ with respect to $\mathrm{T}_{0}$ were observed. In contrast, no significant difference were found between treatments $\mathrm{T}_{0}$ and $\mathrm{T}_{1}$ in WUE $\left(\approx 70 \mu \mathrm{mol} \mathrm{CO}_{2} / \mathrm{mol} \mathrm{H}_{2} \mathrm{O}\right)$. During the second 

in Intensive Agriculture: A Study Case

year, the highest values of $A$ and $g_{s}$ were found in $T_{1}$ $\left(A=12.3 \mu \mathrm{mol} \quad \mathrm{CO}_{2} / \mathrm{m}^{2} / \mathrm{s}\right.$ and $g_{\mathrm{s}}=102.2 \mu \mathrm{mmol}$ $\mathrm{H}_{2} \mathrm{O} / \mathrm{m}^{2} / \mathrm{s}$ ) (Fig. 2b). These differences meant significant $(P<0.05)$ increases in $A$ and $g_{\mathrm{s}}$ of $92 \%$ and $48 \%$, respectively, compared to $\mathrm{T}_{0}$. In contrast, the lowest $A$ and $g_{\mathrm{s}}$ values were found in both $\mathrm{T}_{0}$ and $\mathrm{T}_{2}$, where no significant differences were detected. A significant increase $(P<0.05)$ was also seen for WUE

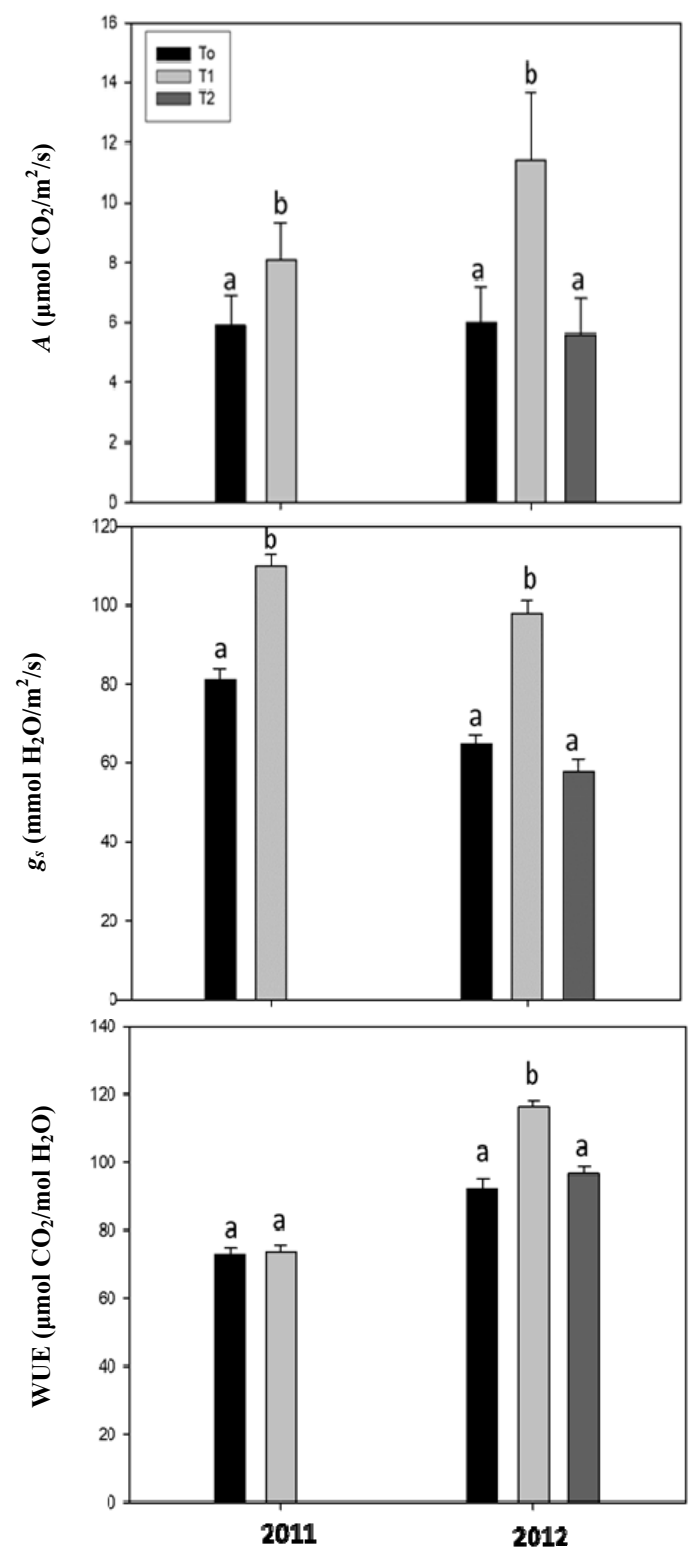

Fig. 2 (a) $A\left(\mu \mathrm{mol} \mathrm{CO} / \mathrm{m}^{2} / \mathrm{s}\right)$, (b) $g_{s}\left(\mathrm{mmol} \mathrm{H}_{2} \mathrm{O} / \mathrm{m}^{2} / \mathrm{s}\right)$ and (c) $\mathrm{WUE}=A / g_{s}\left(\mu \mathrm{mol} \quad \mathrm{CO}_{2} / \mathrm{mol} \mathrm{H}_{2} \mathrm{O}\right)$ for the three treatments applied in this experiment.

Values correspond to the average \pm S.E. of two measurements performed at grape veraison (in early and late July).

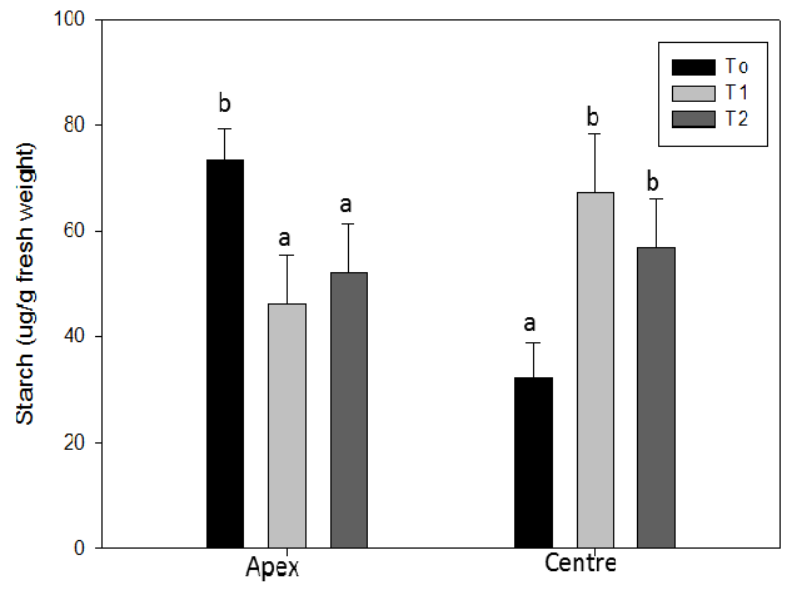

Fig. 3 Starch concentration ( $\mu \mathrm{g} / \mathrm{g}$ fresh weight) at the apex and the central parts of the roots for the three treatments performed, measured in February 2013, after the first two years of the experiment had finished.

Data show the average value \pm S.E.

in $\mathrm{T}_{1}$ in the second year $\left(120.3 \mu \mathrm{mol} \mathrm{CO} / \mathrm{CO}_{2} / \mathrm{mol}_{2} \mathrm{O}\right)$, but not in $\mathrm{T}_{2}$.

\subsubsection{Starch Concentration}

Fig. 3 showed the starch concentration measured at the apex and the central parts of the roots for the three treatments, performed after the first two years of the experiment (February 2013). A similar total starch concentration was measured in $T_{0}, T_{1}$ and $T_{2}$ treatments (105.4, 113.6 and $109.2 \mu \mathrm{g} / \mathrm{g}$, respectively) although there was a slight trend toward increased starch levels with AMF inoculation. In general, this greater accumulation of starch in AMF inoculated grapes agreed with the higher $A$ and WUE data (Fig. 2), as well as with the highest yield (Table 9).

\subsubsection{Yield and Quality of Grapes}

Table 9 presented the yield ( $t / h a)$ for the Crimson grape variety for each year of the experiment. At the end of the first year, the yield in the control treatment $\left(\mathrm{T}_{0}\right)$ was $20.98 \mathrm{t} / \mathrm{ha}$, but inoculation significantly $(P<$ 0.05 ) increased the total yield by $48.3 \%$, to $31.12 \mathrm{t} / \mathrm{ha}$, with respect to $T_{0}$. In inoculated plants $\left(T_{1}\right)$, the yield was unevenly distributed between the first, second and third cut. For $\mathrm{T}_{0}$ in the first year of the experimental period, half the yield was obtained at the first cut.

In the second year, a general reduction in yield compared to the first year was observed. For instance, 
in $\mathrm{T}_{0}$ and $\mathrm{T}_{1}$ yield was reduced by $15 \%$ and $20 \%$, respectively. However, as expected, inoculation significantly $(P<0.05)$ increased the total yield of grapes, compared with the non-inoculated control (increase of 59.1\%). Such increases were also observed in the last cut, as occurred in the first year.

The persistence of AMF, as evaluated in treatment $\mathrm{T}_{2}$, also increased the total yield significantly $(P<$ 0.05 ) but with a more moderate effect (yield of 25.06 $\mathrm{t} / \mathrm{ha}$; an increase of $27.0 \%$ with respect to $\mathrm{T}_{0}$ ). However, in contrast to $T_{1}$, this increase was only observed in the third cut, when most of the yield (c. $80 \%$ ) was harvested.

In the third year, a general increase compared with the other years was observed. At the end of the third year, the yield in the control treatment $\left(\mathrm{T}_{0}\right)$ was 38.18 t/ha, but inoculation significantly $(P<0.05)$ increased this to $51.06 \mathrm{t} /$ ha and $56.00 \mathrm{t} / \mathrm{ha}$ in $\mathrm{T}_{1}$ and $\mathrm{T}_{2}$, respectively. In the second and third year, treatment $\mathrm{T}_{2}$ produced the greatest increases in production with $59.11 \% \quad(25.06 \mathrm{t} / \mathrm{ha})$ and $46.6 \% \quad(56.00 \quad \mathrm{t} / \mathrm{ha})$, respectively, and in both years the production in the first cut was even greater than in previous years by $35.94 \% \quad(4.09 \mathrm{t} / \mathrm{ha})$ and $73.00 \% \quad(17.40 \quad \mathrm{t} / \mathrm{ha})$, respectively.

In treatment $T_{1}$, with a single application of $G$. iranicum var. tenuihypharum, production was still increased in the second and third year of the trial, confirming the residual effect of the strain applied in the first year of the trial in this treatment. However, global production (in three years) was lower than that achieved when plants were inoculated annually, which

Table 9 Yield (t/ha) of Crimson grape variety for the three-year experimental period for the three treatments performed.

\begin{tabular}{llllll}
\hline Year & Treatment & $\begin{array}{l}\text { 1st cut } \\
(\mathrm{kg} / \mathrm{ha})\end{array}$ & $\begin{array}{l}\text { 2nd cut } \\
(\mathrm{kg} / \mathrm{ha})\end{array}$ & $\begin{array}{l}\text { 3rd cut } \\
(\mathrm{kg} / \mathrm{ha})\end{array}$ & $\begin{array}{l}\text { Total } \\
(\mathrm{kg} / \mathrm{ha})\end{array}$ \\
\hline \multirow{2}{*}{2011} & $\mathrm{~T}_{0}$ & $10.47 \pm 2.1$ & $7.41 \pm 1.3$ & $3.10 \pm 0.2$ & $20.98 \pm 2.1$ \\
& $\mathrm{~T}_{1}$ & $12.00 \pm 1.3$ & $10.30 \pm 2.0$ & $8.82 \pm 1.6$ & $31.12 \pm 3.3$ \\
2012 & $\mathrm{~T}_{0}$ & $4.09 \pm 0.2$ & $1.87 \pm 0.2$ & $9.79 \pm 2.1$ & $15.75 \pm 2.1$ \\
& $\mathrm{~T}_{1}$ & $3.46 \pm 1.2$ & $2.06 \pm 0.5$ & $14.49 \pm 1.1$ & $20.01 \pm 2.2$ \\
& $\mathrm{~T}_{2}$ & $5.56 \pm 0.3$ & $9.17 \pm 2.1$ & $10.33 \pm 0.2$ & $25.06 \pm 1.5$ \\
& $\mathrm{~T}_{0}$ & $10.02 \pm 1.2$ & $14.20 \pm 1.2$ & $13.78 \pm 0.6$ & $38.18 \pm 1.2$ \\
& $\mathrm{~T}_{1}$ & $15.10 \pm 1.3$ & $19.70 \pm 2.2$ & $16.26 \pm 3.0$ & $51.06 \pm 2.5$ \\
\hline
\end{tabular}

Data show the average value \pm S.E.

Table 10 Quality fruit parameters for Crimson variety at the two cuts: bunch weight (g), firmness of the grain (pressure in $\mathrm{N} / \mathrm{cm}^{2}$ ), soluble solids concentration $\left({ }^{\circ} \mathrm{Brix}\right)$ and maturity index $\left({ }^{\circ} \mathrm{Brix} / \%\right.$ Tartaric) for the two-year experimental period for the three treatments applied.

\begin{tabular}{|c|c|c|c|c|c|}
\hline Treatment & & 1 st cut & 2nd cut & 1 st cut & 2 nd cut \\
\hline \multirow{3}{*}{ Bunch weight (g) } & $\mathrm{T}_{0}$ & $493 \pm 43$ & $391 \pm 60$ & $617 \pm 51$ & $537 \pm 35$ \\
\hline & $\mathrm{T}_{1}$ & $560 \pm 20$ & $518 \pm 58$ & $876 \pm 40$ & $830 \pm 43$ \\
\hline & $\mathrm{T}_{2}$ & ND & ND & $654 \pm 55$ & $556 \pm 47$ \\
\hline \multirow{3}{*}{ Firmness $\left(\mathrm{N} / \mathrm{cm}^{2}\right)$} & $\mathrm{T}_{0}$ & $62 \pm 1.2$ & $69 \pm 4.1$ & $82 \pm 1.3$ & $86 \pm 1.5$ \\
\hline & $\mathrm{T}_{1}$ & $64 \pm 0.9$ & $69 \pm 3.2$ & $88 \pm 1.5$ & $87 \pm 3.5$ \\
\hline & $\mathrm{T}_{2}$ & ND & ND & $86 \pm 1.6$ & $86 \pm 2.9$ \\
\hline \multirow{3}{*}{ Soluble solids content $\left({ }^{\circ}\right.$ Brix $)$} & $\mathrm{T}_{0}$ & $20 \pm 0.6$ & $20 \pm 0.3$ & $21 \pm 0.4$ & $21 \pm 0.6$ \\
\hline & $\mathrm{T}_{1}$ & $21 \pm 0.4$ & $20 \pm 0.6$ & $21 \pm 0.5$ & $21 \pm 0.4$ \\
\hline & $\mathrm{T}_{2}$ & ND & ND & $21 \pm 0.3$ & $21 \pm 0.5$ \\
\hline \multirow{4}{*}{$\begin{array}{l}\text { Maturity index } \\
\left({ }^{\circ} \text { Brix } / \% \text { Tartaric }\right)\end{array}$} & $\mathrm{T}_{0}$ & $50 \pm 1.1$ & $56 \pm 2.1$ & $46 \pm 3.1$ & $47 \pm 2.9$ \\
\hline & $\mathrm{T}_{1}$ & $53 \pm 1.3$ & $62 \pm 1.6$ & $59 \pm 2.6$ & $60 \pm 3.1$ \\
\hline & $\mathrm{T}_{2}$ & ND & ND & $52 \pm 2.4$ & $55 \pm 2.4$ \\
\hline & \multicolumn{3}{|c|}{ 1st year (2011) } & 2nd year & \\
\hline
\end{tabular}

Data show the average value \pm S.E.; ND: No data during the first year of trial. 
reflected the need for an annual application of the product at the beginning of the growing season.

Table 10 presented the main fruit quality parameters of the harvested grapes during the first two years of the experiment. During the first year, at the first cut, inoculation led to significant $(P<0.05)$ increase in bunch weight (from $493 \mathrm{~g}$ to $560 \mathrm{~g}$ ), berry firmness (from $61.9 \mathrm{~N} / \mathrm{cm}^{2}$ to $64.4 \mathrm{~N} / \mathrm{cm}^{2}$ ), soluble solids concentration (from $20.1{ }^{\circ} \mathrm{Brix}$ to $21.3{ }^{\circ} \mathrm{Brix}$ ) and maturity index (from $50.2^{\circ} \mathrm{Brix} / \%$ Tartaric to 52.8 ${ }^{\circ} \mathrm{Brix} / \%$ Tartaric). No significant differences were detected in the equatorial diameter or berry weight (data not shown). In the second cut, significant $(P<$ 0.05 ) increases in $T_{1}$ were only observed in the bunch weight and maturity index (Table 10).

During the second year, the quality of grapes was noticeably higher with respect to the first year. In the first cut, AMF inoculation led to significant $(P<0.05)$ increases in bunch weight ( $617 \mathrm{~g}$ to $876 \mathrm{~g}$ ), berry firmness $\left(82 \mathrm{~N} / \mathrm{cm}^{2}\right.$ to $\left.88 \mathrm{~N} / \mathrm{cm}^{2}\right)$, maturity index (45.8 ${ }^{\circ} \mathrm{Brix} / \%$ Tartaric to $58.5{ }^{\circ} \mathrm{Brix} / \%$ Tartaric) and in the equatorial diameter (data not shown). However, the berries showed similar soluble solids concentration and weight with respect to $T_{0}$. In $T_{2}$, significant increases were found in the berry firmness (from 82.0 $\mathrm{N} / \mathrm{cm}^{2}$ to $86.1 \mathrm{~N} / \mathrm{cm}^{2}$ ), maturity index (from 55 ${ }^{\circ} \mathrm{Brix} / \%$ Tartaric to $52{ }^{\circ} \mathrm{Brix} / \%$ Tartaric) and equatorial diameter (data not shown). In the second cut, a similar trend was observed. Overall, for treatments $\mathrm{T}_{1}$ and $\mathrm{T}_{2}$, the increase of soluble solid concentration ranged from $1 \%$ to $6 \%$ and, additionally, a reduction of acidity ranging from $10 \%$ to $20 \%$ was observed.

\subsubsection{Discussion}

The study demonstrated that Crimson grapes are heavily dependent on AMF. The successful establishment of the inoculant was confirmed by the fact that the range of root colonization was similar to that reported in previous research [74] and much higher in the second and third year of the experiment. Of note is the observation that the highest percentage of AMF colonization was reached when inoculation was performed during two consecutive years. However, in the second year of the experiment in treatment $\mathrm{T}_{2}$, an expected reduction in AMF colonization compared to $T_{1}$ was detected, although colonization was still much higher than in the control treatment $\left(\mathrm{T}_{0}\right)$. While the high degree of AMF colonization probably meant a high degree of compatibility between the AMF used and plant variety, the reduction in colonization seen in $T_{2}$ might have been due to a certain degree of competition between the native and introduced AMF [75].

A high presence of AMF in the root zone has been shown to aid the uptake of water and to contribute to an improved water status in vines [76]. In that sense, the significant increase observed in the current study in $\psi_{\text {stem }}$ for $T_{1}$ during the first year of the experiment could be attributed to root colonization by AMF. In the second year, the increasing percentage of root colonization, the large amount of water supplied after veraison and improved host $\mathrm{P}$ nutrition probably induced the increase observed in $\psi_{\text {stem }}$ compared to the first year. In fact, the current study highlights the fact that $\psi_{\text {stem }}$ increases as root colonization increases.

The results point to a reduced $\mathrm{N}$ concentration in the inoculated treatment $T_{1}$, regardless of the year of study, although the concentration was always slightly above the optimal range found for the DRIS norm proposed for grapes by García-Escudero et al. [72]. Several growers have reported that the moment of veraison in Crimson grapes is especially complicated, because fully colored ripe and unripe grapes can coexist at the same time. Therefore, it is widely agreed that the fundamental parameter for determining the optimal harvest moment is grape coloration, for which a suitable $\mathrm{N} / \mathrm{K}$ balance must be reached. In the inoculated treatments, regardless of the year of study, the reductions in $\mathrm{N}$ and increases in $\mathrm{K}$ led to a somewhat reduced $\mathrm{N} / \mathrm{K}$ ratio, but similar to that described by Martín et al. [77]. In all treatments, the concentration of $\mathrm{K}$ was always within the optimal 
ranges proposed by DRIS [72].

In the current study, the increase in $\mathrm{P}$ detected in the inoculated treatment $\left(\mathrm{T}_{1}\right)$ was attributed to AMF. In contrast, $\mathrm{T}_{2}$ did not show a significant increase in $\mathrm{P}$, compared to the control treatment $\left(\mathrm{T}_{0}\right)$, which indicates that the reduction in AMF colonization probably conditioned the absorption of this element. As regard the other macronutrients analyzed, $\mathrm{Ca}$ (except in the second year for $\mathrm{T}_{1}$ ) and $\mathrm{Mg}$, no significant differences were found, which agrees with a previous study [23].

Some authors suggest that certain micronutrients may or may not be affected by inoculation with AMF, although there is research that agrees with the results found in the current study, indicating that AMF has no effect on those elements. Bearing all this in mind, it is very likely that the difference in $\mathrm{Zn}$ and $\mathrm{Cu}$, mentioned in the various studies arise from differences in cultivation conditions between studies, as well as from genotypic differences, since the plant response may also change with inoculation of different fungi [78].

At veraison in the first year of the experiment, inoculation increased the $A$ and $g_{s}$ rates significantly, compared to $\mathrm{T}_{0}$, although the high fruit load probably limited photosynthetic activity to a certain extent. However, despite these increases, WUE remained stable. In the second year, the good water status of the grapevines, the higher percentage of root colonization and lower fruit load led to considerably higher values of both $A$ and WUE in treatment $T_{1}$ [79]. In fact, AMF are known to exert a degree of control over transpiration, allowing plants to maintain high levels of WUE [80]. Such an increase, which agrees with other studies in vines [81], may also have accounted for the enhanced growth of plants colonized with Glomus species, most probably as a result of enhanced $\mathrm{CO}_{2}$ fixation [49].

Zapata et al. [73] reported that the $\mathrm{C}$ stored in perennial tissues, such as roots, mainly comprises starch and that its mobilization plays a substantial role in supporting vegetative and reproductive growth. In the current study, it is noticeable that: (1) in non-inoculated grapes, most of the starch was allocated to the apex; (2) in grapes inoculated during the first year but not the second, the starch was equally distributed between the apex and the central part of the root; (3) in grapes inoculated during first and second years, the starch was primarily stored in the central part of the root. In this last case, the decrease in starch at the root apex could indicate that the carbohydrates were destined for the development of new roots and the need to satisfy the energy demand for AMF activity [53]. Also of note is the observation that although plants inoculated only in the first year showed similar $A$, WUE, leaf nutrient content and water potential to plants to the control plants in the second year, the yield was notably increased, especially in the second and third cuts. This could be explained by the higher concentration of starch stored in the center of the root in the first season with respect to the control treatment, which was remobilized to the shoot, increasing fruit set and hence yield [82].

As expected, effective mycorrhizal symbiosis favored the absorption of water and nutrients [51] and hence increased yield. Additionally, the effect of the persistence of the AMF on yield was still significant in $\mathrm{T}_{2}$. Overall, the fruit quality parameters evaluated, bunch weight, firmness, soluble solids concentration and maturity index, were also affected positively. Of particular note is how inoculation significantly increased the soluble solids concentrations and reduced the acid concentration more than proportionally.

\subsubsection{Conclusions}

The selected AMF colonized the Crimson table grape roots satisfactorily. The inoculated grapes had an improved water status, increasing their absorption of some nutrients, such as $\mathrm{P}, \mathrm{K}$ and $\mathrm{Ca}$ and, in addition, both yield and fruit quality were positively affected. Moreover, the ability of AMF to persist in the roots of grape in the second year also produced positive effects. AMF could have favored root development by mobilizing the apex starch reserves, hence, its application led to a higher concentration of 
starch in the central part of the root. Finally, this study suggested that the straightforward application of AMF through a drip irrigation system can be considered a favorable technique. Hence, the development of such symbiosis could be useful in intensive agriculture. Moreover, competition between native and non-native AMF to colonize the soil suggests that the percentage of mycorrhizal colonization should be periodically monitored and re-inoculations be applied to achieve all the positive effects evident in the inoculated treatments.

\subsection{Effectiveness of G. iranicum var. tenuihypharum in Different Crops Systems}

4.3.1 Effect of AM Doses on Tomato Production and Nutrition under Greenhouse Condition

Two different doses of $G$. iranicum var. tenuihypharum sp. nova were applied through a drip irrigation system to evaluate their effects on the physiological, nutritional and agronomic performance of tomato plants. Trials were conducted in South-Eastern Spain under controlled greenhouse conditions from September to December 2012. The high rate of AMF colonization at both applied doses improved plant growth performance, leading to significant increases in leaf macro- (N, P, K, Ca and $\mathrm{Mg}$ ) and micro- ( $\mathrm{Fe}, \mathrm{Cu}, \mathrm{Zn}, \mathrm{Mn}$ and $\mathrm{B}$ ) nutrient concentrations. The AMF present in colonized plants not only exerted some control over the rate of transpiration (stomatal control), but also maintained a higher rate of $A$ and hence improved the intrinsic WUE (computed from the ratio of the rate of $A / g_{s}$ ). In addition, a close relationship was found between the respiratory activity of the AMF and the rate of $A$, leaf $\mathrm{N}, \mathrm{P}, \mathrm{Fe}$ and $\mathrm{K}$ concentrations, and fruit yield (expressed as the product of the average number of fruit $\times$ the average fruit weight in each treatment). In summary, the application of AMF was effective at improving the performance (i.e., the growth, nutrition and yield) of tomato plants cultivated under an intensive fertigation regime [35].

\subsubsection{Protective Effects on Viburnum tinus Plants} Irrigated with Saline Water

The effect of G. iranicum var. tenuihypharum on Laurustinus (V. tinus), a popular shrub much used in gardening, was evaluated under field conditions using two types of water: control, $\mathrm{C}$ with electrical conductivity $(\mathrm{EC})<0.9 \mathrm{dS} / \mathrm{m}$ and reclaimed water (wastewater previously treated in a sewage treatment plant) with EC $4 \mathrm{dS} / \mathrm{m}$ during a first saline period (11 weeks) and with EC $6 \mathrm{dS} / \mathrm{m}$ during a second saline period ( 25 weeks). The chemical properties of the soil, as well as the physiological behavior, leaf nutrition and aesthetic value of plants were evaluated. Due to the high salinity of the wastewater $(6 \mathrm{dS} / \mathrm{m})$, Laurustinus plants decreased their stem water potential values and, to a lesser extent, $g_{s}$. Also, the visual quality of the plants was diminished. The inoculated AMF satisfactorily colonized the laurustinus roots and enhanced the structure of the soil by increasing the glomalin and carbon contents. Furthermore, G. iranicum var. tenuihypharum inoculation decreased the $\mathrm{Na}$ and $\mathrm{Cl}$ contents, stimulated flowering and improved the stem water potential of the plants irrigated with both types of reclaimed water (RW). The AMF also had a positive effect by simulating plant physiological parameters, including stem water potential and $g_{s}$. Effective AMF associations that avoid excessive salinity could provide an outlet for reusing wastewater, especially when plants are grown in heavy soils [39].

4.3.3 Protective Effects on Lettuce Plants Irrigated with Saline Water

The present study also evaluated the effects of inoculation with AMF (G. iranicum var. tenuihypharum sp. nova) on the physiological performance and production of lettuce plants grown under greenhouse conditions and supplied with RW (treated urban wastewater with high EC; $4.19 \mathrm{dS} / \mathrm{m}$ ). Four treatments, fresh water, fresh water plus AMF inoculation, RW and RW plus AMF inoculation, were applied and their effects were analyzed. Root 
mycorrhizal colonization, plant biomass, leaf-ion content, $g_{s}$ and $A$ were assessed. Overall, the results underline the significance of AMF for alleviating salt stress and its beneficial effects on plant growth and productivity. Inoculated plants showed an increased ability to acquire $\mathrm{N}, \mathrm{Ca}$ and $\mathrm{K}$ from both non-saline and saline media. Moreover, mycorrhization significantly reduced plant Na uptake. Even with RW, inoculated plants also showed improvements in physiological parameters, such as $A, g_{s}$ and WUE, compared with non-mycorrhizal plants. Additionally, the high concentration of nutrients dissolved in reclaimed water suggests that farmers should adjust fertigation accordingly. Finally, this experiment demonstrated that mycorrhization could be a suitable way to induce salt stress resistance in iceberg lettuce crops, since the plants irrigated with RW satisfied minimum legal commercial size thresholds. Moreover, the maximum values of Escherichia coli in the RW were close to, but never exceeded established international thresholds (Spanish Royal Decree 1620/2007; Italian Decree, 2003) and so the lettuces were suitable for sale [36].

4.3.4 Effect on the Nutritional Response of Pepper Plants Grown on Coconut Fiber

An experiment was carried out with pepper plants (Capsicum annuum L.) grown on coconut fiber and inoculated with the species G. iranicum var. tenuihypharum, in order to study how well the fungus establishes itself in this type of substrate and the influence of nutrient availability on plant physiology, yield and crop quality. The results showed that treated plants had a higher number of flowers and lateral shoots, possibly related to the improved hormonal expression pattern of treated plants. In addition, an increase in root development and dry matter production was observed in mycorrhized plants, and the fruits were of better quality (greater firmness, in the three samplings carried out and had higher ${ }^{\circ}$ Brix at the last sampling time). The total production of the treatment inoculated with this species was $9.4 \%$ higher than that of the untreated plants at the end of the harvesting period, with a significant increase of $33 \%$ in mycorrhizal production compared with the control at the last cut (August 1st), coinciding with the time the plants entered a senescence phase caused by the effect of the high temperatures characteristic of this summer period [83].

\subsubsection{Effects on Phytochemical Content in} Strawberry Fruits

The effect of inoculation date using AMF on the fruit quality and the phytochemical content of strawberry plants grown in a soilless growing system was analyzed. The experiment was performed in Huelva (Spain) and was conducted in a greenhouse on the La Rábida Campus of Huelva University under natural light and temperature conditions from October 2013 to June 2014. Three short-day strawberry cultivars ("Splendor", "Sabrina" and "Fortuna") were grown in polyethylene bags filled with coconut fibers in a randomized block design, with three repetitions and factorial arrangement ( 3 cultivars $\times 3$ treatments). Each replicate consisted of one bag with 12 plants supporting structures at $40 \mathrm{~cm}$ height. The treatments were: $\mathrm{T}_{1}=$ mycorrhizal inoculation at transplantation, $\mathrm{T}_{2}=$ mycorrhizal inoculation $30 \mathrm{~d}$ after transplantation (DAT) and $\mathrm{T}_{0}=$ control treatment, without inoculation. AMF inoculation significantly affected the anthocyanin and phenolic contents, both of which were higher when inoculation was performed at transplantation $(514 \mathrm{mg} / 100 \mathrm{~g}$ and $235.6 \mathrm{mg} / 100 \mathrm{~g}$ fruit fresh weight, respectively). Mycorrhizal inoculation also decreased the acidity of fruit throughout the growing season and increased firmness, but only during the early stage of production. Similar treatments applied to Fortuna variety led to an even higher anthocyanin content $(514.04 \mathrm{mg} / 100 \mathrm{~g}$ fruit fresh weight) [40].

4.3.6 Effects on Root Architecture and Productivity of Melon

The effect of inoculation with the AMF G. iranicum var. tenuihypharum on the root development and yield 
of melon plants (Cucumis melo L. cv. Hispano de Nuhnems), grown in soil in an intensive agricultural system for three months, was evaluated by measuring the root length, root volume, area, number of root tips, rhizosphere activity, yield and crop quality. The inoculated melon plants had an increased percentage of colonization, which had reached $75 \%$ by the completion of the assay. This meant that the inoculated plants exhibited greater rhizosphere activity, both bacterial and fungal, than the control plants. Inoculation resulted in greater root length, volume and area, and a greater number of tips with a diameter of less than $0.5 \mathrm{~mm}$, indicating greater proliferation of lateral roots and a significant change in the root architecture. In addition, the plants showed higher fruit number and length, yield and fruit sugar content than untreated plants. Therefore, the mycorrhizal association had a strong positive effect on the architecture and root activity, stimulating the capacity for nutrient absorption and resulting in a higher yield and fruit quality (www.symborg.com).

4.3.7 Physiological and Agronomic Influence on Pepper Plants Grown under Greenhouse Conditions

The arbuscular mycorrhiza G. iranicum var. tenuihypharum significantly $(P<0.05)$ influenced plant physiology (better water status and higher gas exchange levels) and the productivity of a pepper crop cultivated under greenhouse conditions in El Ejido (Almeria, Spain), following the cultural practices of the area. The inoculant was not only efficient during the early stages but throughout the whole experiment, enhancing nutrient uptake and physiological characteristics and improving the plant defense system against stress conditions, such as the low winter temperatures. The cultural practices of the area include keeping the fruits on the plants until midwinter (February), when the product reaches the highest prices in the market (during the 2011 season, pepper price reached $1.5 € / \mathrm{kg}$ ). For this reason, although a cut of a few kilos was made in
mid-December, most of the peppers (64\% of the total) were harvested in midwinter (from February to mid-March). During the investigation period, 40 plants per treatment were randomly selected and studied in two replications from different areas of the greenhouse. Inoculation with the above species resulted in the gradual growth of plants throughout the experiment, reaching $48 \%$ during the third harvest, which meant an average growth of $15.29 \%$. The final yield increased from $7.39 \mathrm{~kg} / \mathrm{m}^{2}$ in the control treatment to $8.52 \mathrm{~kg} / \mathrm{m}^{2}$ in the biological treatment (www.symborg.com).

\section{G. iranicum var. tenuihypharum, the Basis of Different Biological Inoculant Products and the Development of a New Market}

Symborg is a leader in agricultural biotechnology research, development and innovation. After finding and patenting the new species G. iranicum var. tenuihypharum, the company has developed a multiplication technology that allows large scale production. The process involves an advanced grinding technique that enables different kinds of application, without losing any of the biological properties of the fungus.

Based on G. iranicum var. tenuihypharum, Symborg has developed a line of biological inoculants for application in most agricultural and crop systems: MycoUp $^{\circledR}$ and MycoUp Activ ${ }^{\circledR}$, biological inoculants for irrigation; Resid $\mathrm{MG}^{\circledR}$, biological inoculant in microgranulated form; Resid $\mathrm{HC}^{\circledR}$, biological inoculant for coating seeds.

In seven years, the company has demonstrated constant and effective results, helping growers from all parts of the world to maximize their crop yields, increasing production in almost all crop families (Table 11). The efficacy of the company's products has therefore been shown in most major agricultural areas, climates, soils and agricultural systems, ranging from intensive to extensive (Fig. 4 and Table 11).

G. iranicum var. tenuihypharum's product line is today sold in most major agricultural areas of the 
Table 11 Maximum yields achieved using G. iranicum var. tenuihypharum as biological inoculants, according to crop family, application system and substrate on a global scale.

\begin{tabular}{|c|c|c|c|c|c|}
\hline Continent & Crop family & Substrate & Application System & Product & Máximum yield achieved \\
\hline \multirow{10}{*}{ Europe } & \multirow{2}{*}{ Vegetables } & Soil & Irrigation & MycoUp, MycoUp Activ & $22 \%$ \\
\hline & & Hydropic & Irrigation & MycoUp, MycoUp Activ & $33 \%$ \\
\hline & Fruit trees & Soil & Irrigation & MycoUp, MycoUp Activ & $28 \%$ \\
\hline & \multirow{2}{*}{ Berries } & Soil & Irrigation & MycoUp, MycoUp Activ & $7 \%$ \\
\hline & & Hydropic & Irrigation & MycoUp, MycoUp Activ & $40 \%$ \\
\hline & Cereals & Soil & Planting time & Resid MG & $27 \%$ \\
\hline & Cereals & Soil & Seed treatment & Resid HC & $15 \%$ \\
\hline & Corn & Soil & Planting time & Resid MG & $57 \%$ \\
\hline & Corn & Soil & Seed treatment & Resid HC & $18 \%$ \\
\hline & Citrus & Soil & Irrigation & MycoUp & $19 \%$ \\
\hline \multirow{9}{*}{ America } & \multirow{2}{*}{ Vegetables } & Soil & Irrigation & MycoUp, MycoUp Activ & $40 \%$ \\
\hline & & Hydropic & Irrigation & MycoUp, MycoUp Activ & $27 \%$ \\
\hline & Fruit trees & Soil & Irrigation & MycoUp, MycoUp Activ & $23 \%$ \\
\hline & \multirow{2}{*}{ Berries } & Soil & Irrigation & MycoUp, MycoUp Activ & $32 \%$ \\
\hline & & Hydropic & Irrigation & MycoUp, MycoUp Activ & $21 \%$ \\
\hline & Cereals & Soil & Planting time & Resid MG & $16 \%$ \\
\hline & Cereals & Soil & Seed treatment & Resid HC & $14 \%$ \\
\hline & Corn & Soil & Planting time & Resid MG & $19 \%$ \\
\hline & Corn & Soil & Seed treatment & Resid HC & $16 \%$ \\
\hline \multirow{7}{*}{ Africa } & Vegetables & Soil & Irrigation & MycoUp, MycoUp Activ & $22 \%$ \\
\hline & \multirow{2}{*}{ Berries } & Soil & Irrigation & MycoUp, MycoUp Activ & $9 \%$ \\
\hline & & Hydropic & Irrigation & MycoUp, MycoUp Activ & $33 \%$ \\
\hline & Cereals & Soil & Planting time & Resid MG & $13 \%$ \\
\hline & Cereals & Soil & Seed treatment & Resid HC & $11 \%$ \\
\hline & Corn & Soil & Seed treatment & Resid HC & $18 \%$ \\
\hline & Vegetables & Soil & Irrigation & MycoUp & $22 \%$ \\
\hline \multirow{4}{*}{ Eurasia } & Vegetables & Hydroponic & Irrigation & MycoUp & $17 \%$ \\
\hline & Citrus & Soil & Irrigation & MycoUp & $19 \%$ \\
\hline & \multirow{2}{*}{ Vegetables } & Soil & Irrigation & MycoUp & $19 \%$ \\
\hline & & Hydroponic & Irrigation & MycoUp & $34 \%$ \\
\hline
\end{tabular}

world, creating a new market where demand has been driven by a variety of factors.

Political and social pressure has led to the global agro biostimulant market growing rapidly. In 2014, global sales were around US $\$ 1.4 \mathrm{bn}$ and are projected to reach US $\$ 2.9$ billion by 2021 with a CARG of $10 \%$ to $12 \%$.

In the USA, where organic agriculture has undergone enormous growth since the early 1980s, sustainable farming practices follow strict standards, with emphasis on the use of biological tools. In the USA, G. iranicum var. tenuihypharum has therefore been used as biological inoculant since 2013. This regulatory context has led other countries of the area to follow the USA restrictions in order to export its products to the USA.

Such is the case of Mexico, Chili or Peru where G. iranicum var. tenuihypharum is marketed in its different formulations to cover the demand in extensive and intensive crops.

In Europe, an increasingly strict regulatory climate governing conventional chemical inputs driven by rising health consciousness of society led to the development of a new approach for using biological products. With 72 million tons of cereals produced in Europe, especially in France where 9.6 million ha are 


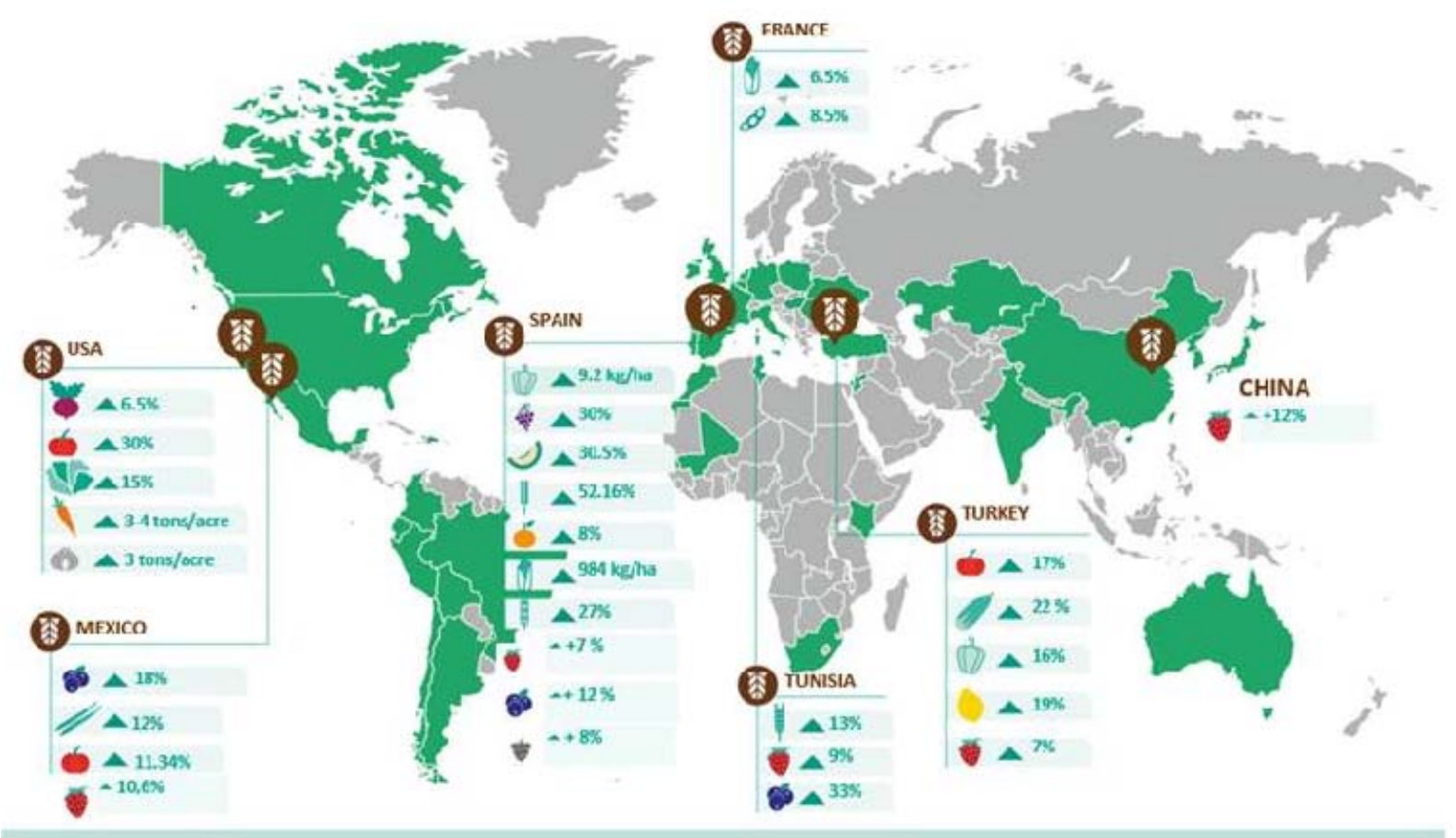

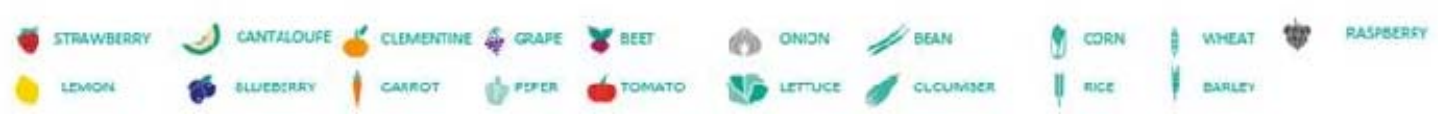

Fig. 4 Global picture and efficacy of MycoUp, MycoUp Activ, Resid MG, Resid HC based on the average of 10 trials.

dedicated to cereal production, G. iranicum var. tenuihypharum, as a component of Resid MG microgranulated and Resid $\mathrm{HC}$ seed treatment formulation are applied on maize, soya and wheat, helping growers to increase their production.

However, worldwide soil deficiency is becoming a major constraint to crop production. Good microbiological management of the soil is essential for growing crops, as it enhances micronutrient translocation to the plant and improves plant immunity. Deficiencies in the microbiological balance affect the quality and quantity of crop production and greater awareness of the problem is leading to the more widespread use of microorganisms in agriculture: the mycorrhizal forming fungus $G$. iranicum var. tenuihypharum, by improving the soil's microbiological properties, is therefore well regarded by the market.

Ever diminishing arable land area is also one of the major factors driving the demand for new biological tools, as a result of the greater pressure on farmers to increase crop production to meet the demand of an increasing population. The increasing prices of agricultural inputs are also driving farmers to invest intelligently in agricultural resources. The application of G. iranicum var. tenuihypharum has helped farmers by increasing the effectiveness of applied micronutrients, thus reducing future expense associated with additional inputs.

The increase usage of modern agricultural practices has contributed to the positive growth seen in the use of G. iranicum var. tenuihypharum in regions, such as Asia-Pacific and Latin America.

The characteristics of $G$. iranicum var. tenuihypharum and its different application forms have led to the Symborg product line based on AMF reaching a global market.

In 2017, G. iranicum var. tenuihypharum is 
marketed and used as biological inoculant in more than 30 countries.

\section{Conclusions}

Although AM symbiosis constitutes the most important microbial association in agronomy and has evolved in most terrestrial environments as an efficient system of nutrient uptake in plants, factors, such as type of soil, high and unbalanced fertilizations levels, and the incorrect selection of strains, will exert a marked influence on the success of the implantation of this technology, making it necessary to choose strains according to the type of soil.

Despite the successful laboratory results obtained with certain strains of AMF, scale-up of their use for agriculture has been slow, probably due to the relative ineffectiveness of the inoculation process, or other factors, such as the technical difficulty involved in their application, the degree of soil compatibility and field carrying capacity.

G. iranicum var. tenuihypharum var. nova was seen to be very effective under a standard fertilization program, differing not only from the controls, for which a lower response might be expected, but also compared with other species of AMF, which, in the case of some variables, led to poorer results than the control. In horticultural crops, the application of this species not only produces significant increases in agricultural production between $10 \%$ and $15 \%$, but also generates a high physiological activity, through increased photosynthetic activity, and an efficient use of water.

Table grapes showed an improved water status, the increased absorption of some nutrients, such as P, K and $\mathrm{Ca}$ and, in addition, both yield and fruit quality were positively affected. Moreover, the ability of AMF to persist in the roots of grape in the second year also had positive effects. AMF could have favored root development by mobilizing the apex starch reserves; hence, its application led to a higher concentration of starch in the central part of the root.
Finally, this study suggested that the straightforward application of AMF through a drip irrigation system can be considered a favorable technique. The development of such symbiosis could be useful in intensive agriculture. Moreover, competition between native and non-native AMF to colonize the soil, suggests that periodic monitoring of the percentage of mycorrhizal colonization should be carried out and that re-inoculation is needed to benefit from all the positive effects evident in the inoculated treatments.

G. iranicum var. tenuihypahrum var. nova is protected by two patents and is a component of MycoUp, MycoUp Activ, Resid HC and Resid MG, whose commercial application has spread to more than 30 countries, achieving increases in crop yields of $8 \%-45 \%$ in lines as varied as leaf vegetables, berries, fruit, olives, grapes, greenhouse crops and cereals.

\section{References}

[1] Turner, B. L., and Doolittle, W. E. 1978. "The Concept and Measure of Agricultural Intensity." Profess. Geogr. 30 (3): 297-301.

[2] Fumagalli, M., Acutis, M., Mazzetto, F., Vidotto, F., Sali, G., and Bechini, L. 2011. "An Analysis of Agricultural Sustainability of Cropping Systems in Arable and Dairy Farms in an Intensively Cultivated Plain.” Eur. J. Agron. 34 (2):71-82.

[3] Temme, A. J. A. M., and Verburg, P. H. 2011. "Mapping and Modelling of Changes in Agricultural Intensity in Europe.” Agric. Ecosyst. Environ. 140 (1-2): 46-56.

[4] Bender, S. F., Conen, F., and Van der Heijden, M. G. A. 2015. "Mycorrhizal Effects on Nutrient Cycling, Nutrient Leaching and $\mathrm{N}_{2} \mathrm{O}$ Production in Experimental Grassland." Soil Biology \& Biochemistry 80: 283-92.

[5] Tilman, D., Cassman, K. G., Matson, P. A., Naylor, R., and Polasky, S. 2002. "Agricultural Sustainability and Intensive Production Practices." Nature 418 (6898): 671-7.

[6] Foley, J. A. 2005. "Global Consequences of Land Use." Science 309 (5734): 570-4.

[7] Berg, G. 2009. "Plant-Microbe Interactions Promoting Plant Growth and Health: Perspectives for Controlled Use of Microorganisms in Agriculture." Appl. Microbiol. Biotechnol. 84 (1): 11-8. 
[8] Transparency Market Research. 2014. Biofertilizers (Nitrogen Fixing, Phosphate Solubilizing and Others) Market for Seed Treatment and Soil Treatment Applications-Global Industry Analysis, Size, Share, Growth, Trends and Forecast, 2013-2019. Transparency Market Research, Allbany NY.

[9] Owen, D., Williams, A. P., Griffith, G. W., and Withers, P. J. A. 2014. "Use of Commercial Bio-inoculants to Increase Agricultural Production through Improved Phosphorus Acquisition.” Appl. Soil Ecol. 86: 41-54.

[10] Van der Heijden, M. G. A., Martin, F. M., Selosse, M. A., and Sanders, I. A. 2015. "Mycorrhizal Ecology and Evolution: The Past, the Present, and the Future." Tansley Review. New Phytologist 205 (4): 1406-23.

[11] Helgason, T., Merryweather, J. W., Denison, J., Wilson, P., Young, J. P. W., and Fitter, A. H. 2002. "Selectivity and Functional Diversity in Arbuscular Mycorrhizas of Co-occurring Fungi and Plants from a Temperate Deciduous Woodland.” J. Ecol. 90 (2): 371-84.

[12] Leake, J. R., Johnson, D., Donnelly, D. P., Muckle, G. E., Boddy, L., and Read, D. J. 2004. "Networks of Power and Influence: The Role of Mycorrhizal Mycelium in Controlling Plant Communities and Agroecosystem Functioning." Can. J. Bot. 82 (8): 1016-45.

[13] Klironomos, J. N. 2003. "Variation in Plant Response to Native and Exotic Arbuscular Mycorrhizal Fungi." Ecology 84 (9): 2292-301.

[14] Hamel, C. 2007. "Extraradical Arbuscular Mycorrhizal Mycelia: Shadowy Figures in the Soil." In Mycorrhizae in Crop Production: Applying Knowledge, edited by Hamel, C., and Plenchette, C. Binghampton: Haworth, 1-36.

[15] Helgason, T., and Fitter, A. H. 2009. "Natural Selection and the Evolutionary Ecology of the Arbuscular Mycorrhizal Fungi (Phylum Glomeromycota)." J. Exp. Bot. 60 (9): 2465-80.

[16] Feddermann, N., Finlay, R., Boller, T., and Elfstrand, M. 2010. "Functional Diversity in Arbuscular Mycorrhiza-The Role of Gene Expression, Phosphorous Nutrition and Symbiotic Efficiency." Fungal Ecol. 3: 1-8.

[17] Sano, S. M., Abbott, L. K., Solaiman, M. Z., and Robson, A. D. 2002. "Influence of Liming, Inoculum Level and Inoculum Placement on Root Colonization of Subterranean Clover." Mycorrhiza 12 (6): 285-90.

[18] Oehl, F., Redecker, D., and Sieverding, E. 2005. “Glomus badium, a New Sporocarpic Mycorrhizal Fungal Species from European Grasslands with Higher Soil pH." Angewandte Botanik 79: 38-43.

[19] Herrera-Peraza, R. A., Hamel, C., Fernández, F., Ferrer, R. L., and Furrazola, E. 2011. "Soil-Strain Compatibility: The Key to Effective Use of Arbuscular Mycorrhizal Inoculants?" Mycorrhiza 21 (3): 183-93.
[20] Young, C. C., Juang, T. C., and Guo, H. Y. 1986. "The Effect of Inoculation with Vesicular-Arbuscular Mycorrhizal Fungi on Soybean Yield and Mineral Phosphorus Utilization in Subtropical-Tropical Soils." Plant Soil 95 (2): 245-53.

[21] Fernández-Martín, F., Rivera-Espinosa, R. A., Hernández-Jiménez, A., Herrera-Peraza, R. A., and Fernández-Suárez, K. 2005. "Inoculation of Arbuscular Mycorrhizal Fungi and Different Soil: Earthworm Humus Ratios on Coffee Growth (Coffea arabica L.) cv. Catuaí at the Nursery Stage." Revista Chapingo Serie Horticultura 11 (1): 175-84.

[22] Zeuske, D., and Weber, H. C. 2000. "Growth Stimulation of Panax ginseng C.A. Meyer (Araliaceae) Arising from AMF-Isolate Inoculation." Symbiosis 29: 213-23.

[23] Schreiner, P. R. 2007. "Effects of Native and Non-native Arbuscular Mycorrhizal Fungi on Growth and Nutrient Uptake of 'Pinot Noir' (Vitis vinifera L.) in Two Soils with Contrasting Levels of Phosphorus." Appl. Soil Ecol. 36 (2-3): 205-15.

[24] Liu, A., Hamel, C., Hamilton, R. I., and Smith, D. L. 2000. "Mycorrhizae Formation and Nutrient Uptake of New Corn (Zea mays L.) Hybrids with Extreme Canopy and Leaf Architecture as Influenced by Soil $\mathrm{N}$ and $\mathrm{P}$ Levels." Plant Soil 221 (2): 157-66.

[25] Brundrett, M. C. 2009. "Mycorrhizal Associations and Other Means of Nutrition of Vascular Plants: Understanding the Global Diversity of Host Plants by Resolving Conflicting Information and Developing Reliable Means of Diagnosis." Plant and Soil 320 (1-2): 37-77.

[26] Gilbert, N. 2009. "The Disappearing Nutrient." Nature 461 (7265): 716-8.

[27] Ryan, M. H., and Graham, J. H. 2002. "Is There a Role for Arbuscular Mycorrhizal Fungi in Production Agriculture?" Plant and Soil 244 (1-2): 263-71.

[28] Gentili, F., and Jumpponen, A. 2006. "Potential and Possible Uses of Bacterial and Fungal Biofertilizers." In Handbook of Microbial Biofertilizers, edited by Rai, M. K. Lucknow, India: International Book Distributing Co., $1-28$.

[29] Wiseman, P. E., Colvin, K. H., and Wells, C. E. 2009. "Performance of Mycorrhizal Products Marketed for Woody Landscape Plants." J. Environ. Hortic. 27 (1): 41-50.

[30] Hamel, C., Dalpé, Y., Furlan, V., and Parent, S. 1997. "Indigenous Populations of Arbuscular Mycorrhizal Fungi and Soil Aggregate Stability are Major Determinants of Leek (Allium porrum L.) Response to Inoculation with Glomus intraradices Schenck \& Smith or Glomus versiforme (Karsten) Berch." Mycorrhiza 7: 187-96. 


\section{Application of Arbuscular Mycorrhizae Glomus iranicum var. tenuihypharum var. nova in Intensive Agriculture: A Study Case}

[31] Antunes, P. M., Koch, A. M., Dunfield, K. E., Hart, M. M., Downing, A., Rillig, M. C., and Klironomos, J. N. 2009. "Influence of Commercial Inoculation with Glomus intraradices on the Structure and Functioning of an AM Fungal Community from an Agricultural Site.” Plant Soil 317 (1-2): 257-66.

[32] Cozzolino, V., Di Meo, V., and Piccolo, A. 2013. "Impact of Arbuscular Mycorrhizal Fungi Applications on Maize Production and Soil Phosphorus Availability." Journal of Geochemical Exploration 129: 40-4.

[33] Feng, G., Zhang, F. S., Li, X. L., Tian, C. Y., Tang, C., and Rengel, Z. 2002. "Improved Tolerance of Maize Plants to Salt Stress by Arbuscular Mycorrhiza Is Related to Higher Accumulation of Soluble Sugars in Roots." Mycorrhiza 12 (4): 185-90.

[34] Corkidi, L., Allen, E. B., Merhaut, D., Allen, M. F., Downer, J., Bohn, J., and Evans, M. 2004. "Assessing the Infectivity of Commercial Mycorrhizal Inoculants in Plant Nursery Conditions." J. Environ. Hortic. 22 (3): 149-54.

[35] Fernández, F., Vicente-Sánchez, J., Maestre-Valero, J. F., Bernabé, A. J., Pedrero, F., and Alarcón, J. J. 2014. "Physiological and Growth Responses of Young Tomato Seedlings to Drip-Irrigation Containing Two Low Doses of the Arbuscular Mycorrhizal Fungus Glomus iranicum var. tenuihypharum sp. nova." J. Hortic. Sci. Biotechnol. 89 (6): 679-85.

[36] Vicente-Sánchez, J., Nicolas, E., Pedrero, F., Alarcon, J. J., Maestre-Valero, J. F., and Fernández, F. 2014. "Arbuscular Mycorrhizal Symbiosis Alleviates Detrimental Effects of Saline Reclaimed Water in Lettuce Plants." Mycorrhiza 24 (5): 339-48.

[37] Nicolás, E., Maestre-Valero, J. F., Alarcón, J. J., Pedrero, F., Vicente-Sánchez, J., Bernabé, A., Gómez-Montiel, J., Hernández, J. A., and Fernández, F. 2014. "Effectiveness and Persistence of Arbuscular Mycorrhizal Fungi on the Physiology, Nutrient Uptake and Yield of Crimson Seedless Grapevine.” Journal of Agricultural Science 153 (6): 1084-96.

[38] Fernández, F., Dell Amico, J. M., Alarcón, J. J., Nicolás, E., and Pedrero, F. 2010. "Improved Rice Crop Yield by Applying Isolated Mycorrhizae under Saline Conditions." Revista Agricultura 916-9.

[39] Gómez-Bellot, M., Ortuño, M. F., Nortes, P. A., Vicente-Sánchez, J., Martín, F. F., Bañón, S., and Sánchez-Blanco, M. J. 2015. "Protective Effects of Glomus iranicum var. tenuihypharum on Soil and Viburnum tinus Plants Irrigated with Treated Wastewater under Field Conditions.” Mycorrhiza 25 (5): 399-409.

[40] Cecatto, A., Martínez, F. R., Oliveira, E., Martínez, J., and Palencia, P. 2016. "Mycorrhizal Inoculation Affects the Phytochemical Content in Strawberry Fruits." Acta
Scientiarum, Agronomy Maringá 38 (2): 227-37.

[41] Hart, M. M., Forsythe, J. A. 2012. "Using Arbuscular Mycorrhizal Fungi to Improve the Nutrient Quality of Crops; Nutritional Benefits in Addition to Phosphorus." Sci. Hortic. 148: 206-14.

[42] Adholeya, A., Tiwari, P., and Singh, R. 2005. "Large Scale Inoculum Production of Arbuscular Mycorrhizal Fungi on Root Organs and Inoculation Strategies.” In Soil Biology in Vitro Culture of Mycorrhizae, edited by Declerck, S., Strullu, D. G., and Fortin, A. Heidelberg, Berlin: Springer-Verlag, 315-38.

[43] Porte, N. W. 1979. "The 'Most Probable Number' Method for Enumerating Infective Propagules of Vesicular Arbuscular Mycorrhizal Fungi in Soil." Australian Journal of Soil Research 17 (3): 515-9.

[44] Phillips, D. M., and Hayman, D. S. 1970. "Improved Procedures for Clearing Roots and Staining Parasitic and Vesicular Arbuscular Mycorrhizal Fungi for Rapid Assessment of Infection." Transactions of the British Mycological Society 55 (1): 158-61.

[45] Wright, S. F., Franke-Snyder, M., Morton, J. B., and Upadhyaya, A. 1996. "Time Course Study and Partial Characterization of a Protein on Hyphae of Arbuscular Mycorrhizal Fungi during Active Colonization of Roots." Plant and Soil 181 (2): 193-203.

[46] Ryder, E. J. 1979. Leafy Salad Vegetables. Connecticut, USA: AVI Publishing Company, Inc., 94.

[47] Jahromi, F., Aroca, R., Porcel, R., and Ruíz-Lozano, J. M. 2008. "Influence of Salinity on the in Vitro Development of Glomus intraradices and on the in Vivo Physiological and Molecular Responses of Mycorrhizal Lettuce Plants.” Microb. Ecol. 55 (1): 45-53.

[48] Ruíz-Lozano, J. M., and Azcón, R. 1996. "Mycorrhizal Colonization and Drought Stress Exposition as Factors Affecting Nitrate Reductase Activity in Lettuce Plants." Agric. Ecosyst. Environ. 60: 175-81.

[49] Aroca, R., Ruíz-Lozano, J. M., Zamarreño, A., Paz, A., García-Mina, J. M., Pozo, M. J., and López-Ráez, J. A. 2013. "Arbuscular Mycorrhizal Symbiosis Influences Strigolactone Production under Salinity and Alleviates Salt Stress in Lettuce Plants.” J. Plant Physiol. 170 (1): 47-55.

[50] Baslam, M., Garmendia, I., and Goicoechea, N. 2011. “Arbuscular Mycorrhizal Fungi (AMF) Improved Growth and Nutritional Quality of Greenhouse-Grown Lettuce.” J. Agric. Food Chem. 59 (10): 5504-15.

[51] Navarro, A., Bañon, S., Morte, A., and Sánchez-Blanco, M. J. 2011. "Effects of Nursery Preconditioning through Mycorrhizal Inoculation and Drought in Arbutus unedo L. Plants." Mycorrhiza 21 (1): 53-64.

[52] Kapoor, R., Sharma, D., and Bhatnagar, A. K. 2008. "Arbuscular Mycorrhizae in Micropropagation Systems 
and Their Potential Applications." Sci. Hortic. 116 (3): 227-39.

[53] Marjanović, Z., and Nehls, U. 2008. "Ectomycorrhiza and Water Transport." Mycorrhiza 149-59.

[54] Hodge, A., Campbell, C. D., and Fitter, A. H. 2001. “An Arbuscular Mycorrhizal Fungus Accelerates Decomposition and Acquires Nitrogen Directly from Organic Material.” Nature 413: 297-9.

[55] Johansen, A., Finlay, R. D., and Olsson, P. A. 1996. "Nitrogen Metabolism of External Hyphae of the Arbuscular Mycorrhizal Fungus Glomus intraradices." New Phytol. 133 (4): 705-12.

[56] Hirrel, M. C., and Gerdemann, J. W. 1980. "Improved Growth of Onion and Bell Pepper in Saline Soils by Two Vesicular-Arbuscular Mycorrhizal Fungi." Soil Sci. Soc. Am. J. 44: 654-5.

[57] Evelin, H., Giri, B., and Kapoor, R. 2012. "Ultrastructural Evidence for AMF Mediated Salt Stress Mitigation in Trigonella foenum-graecum." Mycorrhiza 23 (1): 71-86.

[58] Cantrell, I. C., and Linderman, R. G. 2001. "Preinoculation of Lettuce and Onion with VA Mycorrhizal Fungi Reduces Deleterious Effects of Soil Salinity." Plant and Soil 233 (2): 269-81.

[59] Baslam, M., Pascual, I., Sánchez-Díaz, M., Erro, J., García-Mina, J. M., and Goicoechea, N. 2011. "Improvement of Nutritional Quality of Greenhouse-Grown Lettuce by Arbuscular Mycorrhizal Fungi Is Conditioned by the Source of Phosphorus Nutrition.” J. Agric. Food Chem. 59 (20): 11129-40.

[60] Hartz, T., Jonhstone, P. R., Williams, E., and Smith, R. F. 2007. "Establishing Lettuce Leaf Nutrient Optimum Ranges through DRIS Analysis." Hortscience 42 (1): 143-6.

[61] Jones, J. B., Wolf, B., and Mills, H. A. 1991. Plant Analysis Handbook. Athens: Micro-Macro, 213.

[62] Hochmuth, G., Maynard, D., Vavrina, C., and Hanlon, E. 1991. Plant Tissue Analysis and Interpretation for Vegetable Crops in Florida. Univ. Florida Special Publication SS-VEC-42.

[63] Van den Driessche, R. 1991. "Effects of Nutrients on Stock Performance in the Forest." In Mineral Nutrition of Conifer Seedlings. Boca Raton, FL: CRC, 229-60.

[64] Querejeta, J. I., Barea, J. M., Allen, M. F., Caravaca, F., and Roldán, A. 2003. "Differential Response of $\delta^{13} \mathrm{C}$ and Water Use Efficiency to Arbuscular Mycorrhizal Infection in Two Arid Land Woody Plant Species." Oecologia 135 (4): 510-5.

[65] Schubert, A., Cammarata, S., and Eynard, I. 1988. "Growth and Root Colonization of Grapevines Inoculated with Different Mycorrhizal Endophytes." Horticultural Science 23 (2): 302-3.

[66] Schellenbaum, L., Berta, G., Ravolanirina, F., Tisserant,
B., Gianinazzi, S., and Fitter, A. H. 1991. "Influence of Endo-Mycorrhizal Infection on Root Morphology in a Micro-propagated Woody Plant Species (Vitis vinifera L.)." Annals of Botany 68 (2): 135-41.

[67] Waschkies, C., Schropp, A., and Marschenr, H. 1994. "Relations between Grapevine Replant Disease and Root Colonization of Grapevine (Vitis sp.) by Fluorescent Pseudomonads and Endomycorrhizal Fungi." Plant and Soil 162 (2): 219-27.

[68] Juarez, J., and Fernandez, F. 2015. Glomus iranicum var. tenuihypharum var. nov. Strain and Use Thereof as Bio-stimulant. Patent WIPO No: WO/2015/000612.

[69] Begg, J. E., and Turner, N. C. 1970. "Water Potential Gradients in Field Tobacco." Plant Physiology 46 (2): 343-6.

[70] Pou, A., Medrano, H., Tomàs, M., Martorell, S., Ribas-Carbó, M., and Flexas, J. 2012. "Anisohydric Behaviour in Grapevines Results in Better Performance under Moderate Water Stress and Recovery than Isohydric Behaviour." Plant and Soil 359 (1-2): 335-49.

[71] Watson, M. E., and Galliher, T. L. 2001. "Comparison of Dumas and Kjeldahl Methods with Automatic Analyzers on Agricultural Samples under Routine Rapid Analysis Conditions." Communications in Soil Science and Plant Analysis 32 (13-14): 2007-19.

[72] García-Escudero, E., Romero, I., Benito, A., Domínguez, N., and Martín, I. 2013. "Reference Levels for Leaf Nutrient Diagnosis of cv. Tempranillo Grapevine in the Rioja Appellation." Communications in Soil Science and Plant Analysis 44 (1-4): 645-54.

[73] Zapata, C., Deléen, S. E., Chaillou, S., and Magné, C. 2004. "Partitioning and Mobilization of Starch and N Reserves in Grapevine (Vitis vinifera L.)." Journal of Plant Physiology 161 (9): 1031-40.

[74] Caglar, S., and Bayram, A. 2006. "Effects of Vesicular-Arbuscular Mycorrhizal (VAM) Fungi on the Leaf Nutritional Status of Four Grapevine Rootstocks." European Journal of Horticultural Science 71 (3): 109-13.

[75] Verbruggen, E., Van Der Heijden, M. G. A., Rilling, M. C., and Kiers, E. T. 2013. "Mycorrhizal Fungal Establishment in Agricultural Soils: Factors Determining Inoculation Success." New Phytologist 197 (4): 1104-9.

[76] Ruíz-Lozano, J. M., and Azcón, R. 1995. "Hyphal Contribution to Water Uptake in Mycorrhizal Plants as Affected by the Fungal Species and Water Status." Physiologia Plantarum 95 (3): 472-8.

[77] Martín, I., Benito, A., Romero, I., Domínguez, N., and García-Escudero, E. 2013. "Preliminary Diagnosis and Recom-Mendation Integrated System Norms for Leaf Nutrient Diagnosis of Tempranillo Grapevine in the Rioja Appellation." Communications in Soil Science and Plant 
Analysis 44 (1-4): 655-67.

[78] Kafkas, S., and Ortas, I. 2009. "Various Mycorrhizal Fungi Enhance Dry Weights, $\mathrm{P}$ and Zn Uptake of Four Pistacia Species." Journal of Plant Nutrition 32 (1): 146-59.

[79] Evelin, H., Kapoor, R., and Giri, B. 2009. "Arbuscular Mycorrhizal Fungi in Alleviation of Salt Stress: A Review." Ann. Bot. 104 (7): 1263-80.

[80] Navarro-Ródenas, A., Bárzana, G., Nicolás, E., Carra, A., Schubert, A., and Morte, A. 2013. "Expression Analysis of Aquaporins from Desert Truffle Mycorrhizal Symbiosis Reveals a Fine-Tuned Regulation under Drought." Molecular Plant-Microbe Interactions 26 (9): 1068-78.

[81] Nikolaou, N. A., Koukourikou, M., Angelopoulos, K., and Karagiannidis, N. 2003. "Cytokinin Content and Water Relations of 'Cabernet Sauvignon' Grapevine Exposed to Drought Stress." The Journal of Horticultural Science and Biotechnology 78 (1): 113-8.

[82] Bennett, J. S. 2002. "Relationships between Carbohydrate Supply and Reserves and the Reproductive Growth of Grapevines (Vitis vinifera L.)." Ph.D. thesis, Lincoln University, Canterbury, New Zealand.

[83] Alcobendas, R., Parra, M., Bayona, J. M., Fernández, F., Romero-Triguero, C., Nicolas, E., and Alarcón, J. J. 2016. "Physiological and Agronomic Response of Pepper Plants Grown in Coconut Fiber." In Proceeding of $X \mathrm{~V}$ Congreso Nacional de Ciencias Hortícolas, SECH, Orihuela. (in Spanish) 